NBSIR 82-2606

\title{
A Model of the Steady-State Performance of An Absorption Heat Pump
}

U.S. DEPARTMENT OF COMMERCE National Bureau of Standards National Engineering Laboratory Center for Building Technology

Washington, DC 20234

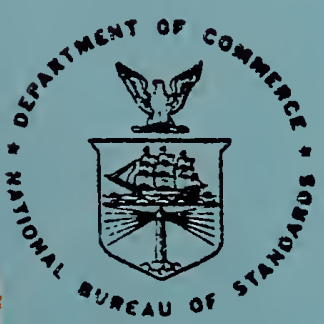





HEAT PUMP

Dr. S. A. Klein

U.S. DEPARTMENT OF COMMERCE

National Bureau of Standards

National Engineering Laboratory

Center for Building Technology

Washington, DC 20234

October 1982

U.S. DEPARTMENT OF COMMERCE, Malcolm Baldrige, Secretary NATIONAL BUREAU OF STANDARDS. Ernest Ambler, Director 


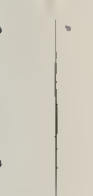




\section{ABSTRACT}

A mathematical model of the steady-state performance of an absorption heat pump is described. The model is compared with experimental data from a residentialsized water chiller. Ic is also used to determine the sensitivity of the heat pump performance to its design variables. 


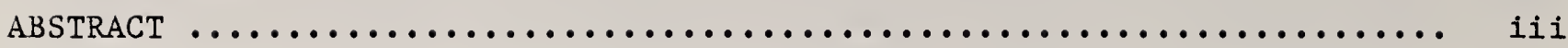

LIST OF FIGURES $\ldots \ldots \ldots \ldots \ldots \ldots \ldots \ldots \ldots \ldots \ldots \ldots \ldots \ldots \ldots \ldots \ldots \ldots \ldots \ldots \ldots$

LIST OF TABLES $\ldots \ldots \ldots \ldots \ldots \ldots \ldots \ldots \ldots \ldots \ldots \ldots \ldots \ldots \ldots \ldots \ldots \ldots \ldots \ldots \ldots$

1. INTRODUCTION $\ldots \ldots \ldots \ldots \ldots \ldots \ldots \ldots \ldots \ldots \ldots \ldots \ldots \ldots \ldots \ldots \ldots \ldots \ldots \ldots$

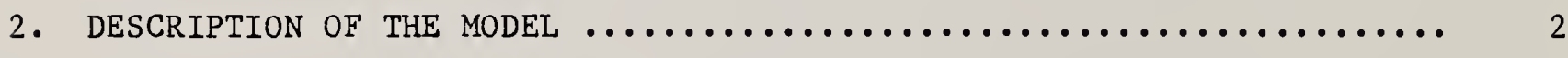

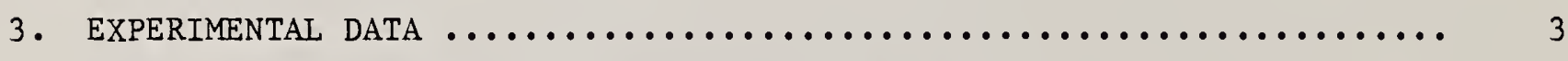

4. COMPARISON OF THE MODEL TO EXPERIMENTAL DATA ................. 21

5. EFFECTS OF MODEL PARAMETERS $\ldots \ldots \ldots \ldots \ldots \ldots \ldots \ldots \ldots \ldots \ldots \ldots \ldots \ldots \ldots \ldots . \ldots \ldots$

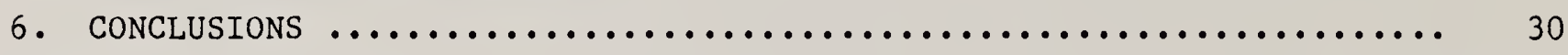

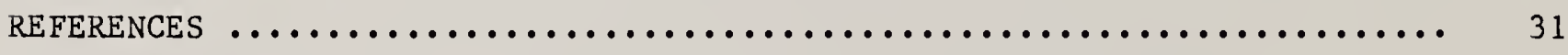

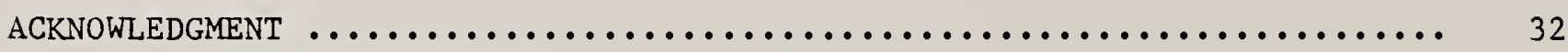

APPENDIX A. PROPERTY DATA ROUTINES $\ldots \ldots \ldots \ldots \ldots \ldots \ldots \ldots \ldots \ldots \ldots \ldots \ldots \ldots \ldots$ A

APPENDIX B. PROGRAM LISTING $\ldots \ldots \ldots \ldots \ldots \ldots \ldots \ldots \ldots \ldots \ldots \ldots \ldots \ldots \ldots \ldots \ldots$ 


\section{LIST OF FIGURES}

Page

Figure 1. Schematic Diagram of the ARKLA Chiller, Model No. ACC-36-00 .. 3

Figure 2. Thermocouple Locations $\ldots \ldots \ldots \ldots \ldots \ldots \ldots \ldots \ldots \ldots \ldots \ldots \ldots$ 
Page

Table 1. ARKLA Unit Thermocouple Locations $\ldots \ldots \ldots \ldots \ldots \ldots \ldots \ldots \ldots \ldots \ldots . . \ldots$

Table 2. Steady-state Test Data at $80^{\circ} \mathrm{F} \ldots \ldots \ldots \ldots \ldots \ldots \ldots \ldots \ldots . \ldots \ldots$

Table 3. Steady-state Test Data at $95^{\circ} \mathrm{F} \ldots \ldots \ldots \ldots \ldots \ldots \ldots \ldots \ldots \ldots$

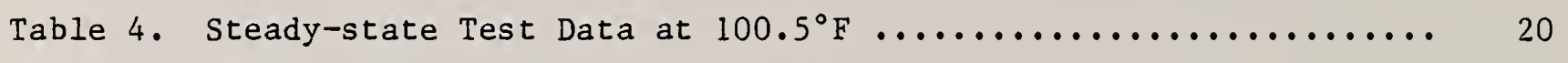

Table 5. Parameter Values Used in Comparisons .................. 22

Table 6. Calculated Results for $\mathrm{T}_{\text {air }}=95^{\circ} \mathrm{F} \ldots \ldots \ldots \ldots \ldots \ldots \ldots \ldots \ldots$

Table 7. Calculated Results for $\mathrm{T}_{\mathrm{air}}=80^{\circ} \mathrm{F} \ldots \ldots \ldots \ldots \ldots \ldots \ldots \ldots \ldots . \ldots \ldots$

Table 8. Calculated Results for $\mathrm{T}_{\mathrm{air}}=100.5^{\circ} \mathrm{F} \ldots \ldots \ldots \ldots \ldots \ldots \ldots . \ldots . \ldots . \ldots$ 


\section{INTRODUCTION}

A mathematical model of the steady-state performance of an absorption heat pump has been developed and coded into a FORTRAN program. The model is based on mass and energy balances about each system component and it incorporates heat transfer rate limitations. A detailed description of the model appears in section 2 .

One application for this model is to check the consistency of experimental data. Thus far, the model has been compared with the steady-state performance of an ARKLA 3-ton ammonia-water chiller (model no. ACC 3600). The experimental data are reported in section 3. Comparisons of the model to these data appear in section 4 .

The model can also be a useful tool in the analysis and design of absorption heat pumps through sensitivity studies. Used in this manner, the model indicates how the steady-state performance is affected by changes in the design parameters or operating conditions. The results of a sensitivity study are reported in section 5 .

The model has been written to be independent of the absorbent-refrigerant system; any absorbent-refrigerant system for which property data are available can be used with the model. The required property data subroutines are described in appendix A. A listing of the program appears in appendix $B$. 


\section{DESCRIPTION OF THE MODEL}

The absorption heat pump model is coded in a modular manner; i.e., a separate FORTRAN subroutine is used for each system component. There are several advantages to this modular approach. First, it allows simulation of many different system configurations without major changes to the model since additional heat exchangers, pumps, throttles, etc. can be included as desired. Second, the modular approach simplifies the program development in that improved component models can be incorporated as they are developed. A disadvantage of the modular approach is that the set of equations describing the heat pump performance can not be solved explicitly. An iterative solution is required.

There are three distinct types of information associated with each component model: parameters, inputs, and outputs. The parameters are the design specifications of the component. In the component models described below, the parameters are primarily factors to account for heat transfer limitations. The inputs to a component are the characteristics of the fluid streams flowing into that component. Each stream has six characteristics:

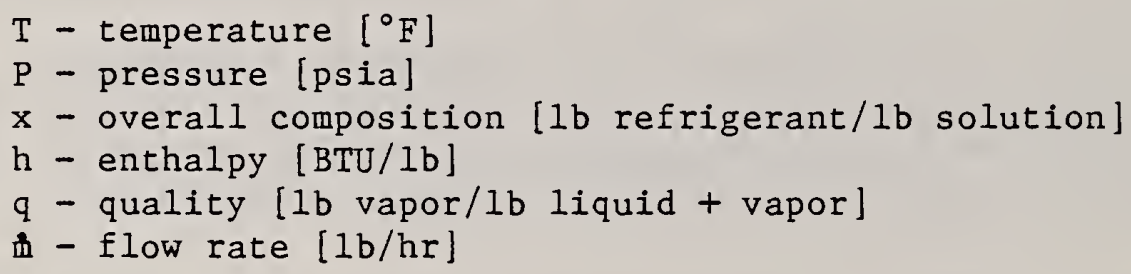

(Other stream characteristics are density, viscosity, thermal conductivity, specific heat, etc., but they are not needed in this model.) The outputs of a component are the characteristics of the outlet streams and any external heat flows such as the evaporator heat input. In steady-state operation, the inputs and outputs are constants with respect to time. The distinction between parameters and inputs is that parameters are known constants specified by the user; the inputs are generally unknown and must be found by an iterative solution technique.

The iterative solution proceeds in the following way. Each component subroutine is designed to calculate the outputs of the component using the supplied parameter and input values. The outputs of one component are inputs to other components in the system. The component subroutines are executed and with each iteration, the input/output values are improved. The order in which the subroutines are executed is unimportant. The iteration proceeds until the outputs (and thus the inputs) of all routines converge. The final solution is thus found by successive substitution.

A schematic diagram of an ARKLA 3-ton chiller is shown in figure 1 . Due to its modular form, the model is not limited to absorption machines of this particular configuration, but the model was developed for the ARKLA unit. Sixteen flow stream locations are identified by numbers in the diagram and are referred to in the component model descriptions below. 


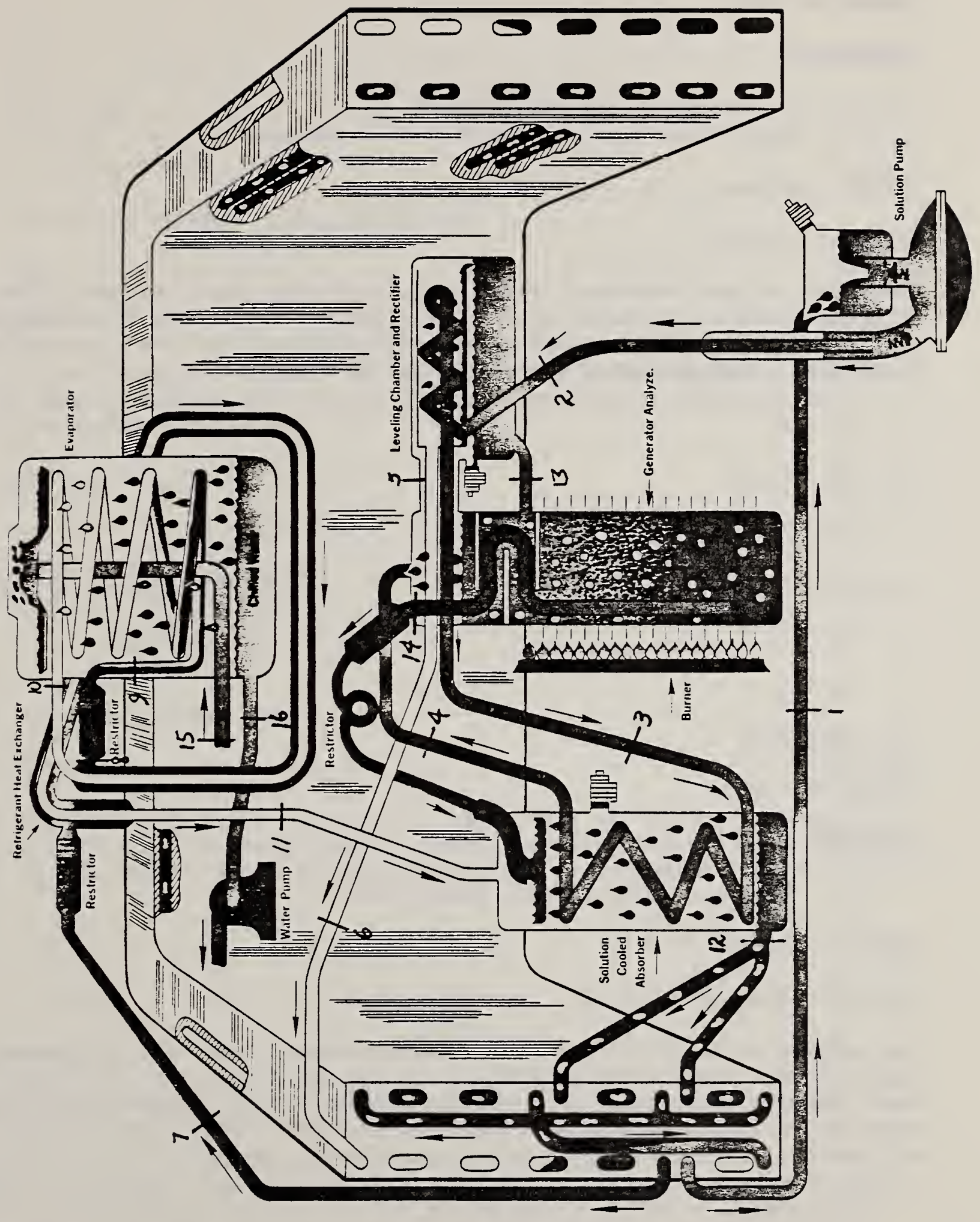

Figure 1. Schematic diagram of ARKLA chiller model ACC-36-00 


\subsection{SOLUTION PUMP}

SUBROUTINE PUMP

\section{PARAMETERS :}

1. $\dot{\mathrm{m}}$ - solution flow rate [lb/hr]

2. Phigh - pressure on high side of cycle [psia]

\section{INPUTS: Stream 1}

\section{OUTPUTS: Stream 2}

The solution pump requires a relatively small work input and has little effect on thermodynamic properties other than pressure. The model is simplistic in that the work input is assumed to be negligible and the flow rate must be specified. A mathematical description is as follows.

$$
\begin{aligned}
& \dot{\mathrm{m}}_{2}=\dot{\mathrm{m}} \\
& \mathrm{p}_{2}=\mathrm{p}_{\text {high }} \\
& \mathrm{T}_{2}=\mathrm{T}_{1} \\
& \mathrm{x}_{2}=\mathrm{x}_{1} \\
& \mathrm{~h}_{2}=\mathrm{h}_{1} \\
& \mathrm{q}_{2}=\mathrm{q}_{1}
\end{aligned}
$$

\subsection{RECTIFIER}

SUBROUTINE RECT

PARAMETERS :

1. (UA) rect - overall heat conductance

INPUTS : Streams 2, 5

OUTPUTS : Streams 3, 6, 13

The purpose of the rectifier is to condense water vapor from the ammonia-water vapor mixture leaving the generator. In the ARKLA unit, the rectifier is a heat exchange coil acting as a partial condenser. In the model, it is assumed that the rectifier is adiabatic and that streams 6 and 13 are in equilibrium so that

$$
\begin{aligned}
& \mathrm{T}_{6}=\mathrm{T}_{13} \\
& \mathrm{P}_{6}=\mathrm{P}_{13}
\end{aligned}
$$


Mass balances yield

$$
\begin{aligned}
& \dot{\mathrm{m}}_{3}=\dot{\mathrm{m}}_{2} \\
& \mathrm{x}_{3}=\mathrm{x}_{2} \\
& \dot{\mathrm{m}}_{6}+\dot{\mathrm{m}}_{13}=\dot{\mathrm{m}}_{5} \\
& \dot{\mathrm{m}}_{6} \mathrm{x}_{6}+\dot{\mathrm{m}}_{13} \mathrm{x}_{13}=\dot{\mathrm{m}}_{5} \mathrm{x}_{5}
\end{aligned}
$$

Pressure losses are assumed to be negligible.

$$
\begin{aligned}
& \mathrm{P}_{6}=\mathrm{P}_{5} \\
& \mathrm{P}_{3}=\mathrm{P}_{2}
\end{aligned}
$$

The rate of heat transfer between the stream flowing within the coil and the condensing vapor is expressed in terms of an overall heat conductance and a log mean temperature difference.

$$
\dot{\mathrm{Q}}=(\mathrm{UA})_{\text {rect }} \Delta \mathrm{T}_{1 \mathrm{~m}}
$$

where

$$
\Delta T_{1 m}=\frac{\left(T_{5}-T_{3}\right)-\left(T_{6}-T_{2}\right)}{\ln \left(\frac{T_{5}-T_{3}}{T_{6}-T_{2}}\right)}
$$

An energy balance requires that

$$
\dot{\mathrm{Q}}=\dot{\mathrm{m}}_{2}\left(\mathrm{~h}_{3}-\mathrm{h}_{2}\right)=\dot{\mathrm{m}}_{5} \mathrm{~h}_{5}-\dot{\mathrm{m}}_{6} \mathrm{~h}_{6}-\dot{\mathrm{m}}_{13} \mathrm{~h}_{13}
$$

Equations 2.2.5 through 2.2 .11 are solved iteratively as follows. A guess is made for $\mathrm{T}_{6}\left(=\mathrm{T}_{13}\right)$. This temperature is used with the property data subroutines to determine the composition and specific enthalpy of streams 6 (vapor) and 13 (1iquid).

$$
\begin{aligned}
x_{13} & =\operatorname{XLPT}\left(P_{13}, T_{13}\right) \\
h_{13} & =H L\left(x_{13}, T_{13}, P_{13}\right) \\
x_{6} & =\operatorname{XV}\left(x_{13}, P_{6}\right) \\
h_{6} & =H V\left(x_{13}, x_{6}, T_{6}, P_{6}\right)
\end{aligned}
$$

The mass flow rates, $\dot{\mathrm{m}}_{6}$ and $\dot{\mathrm{m}}_{13}$, are found from equations 2.2 .5 and 2.2 .6 . Using these flow rates, the rate of heat transfer is evaluated form the righthand side of equation 2.2.11, which then determines $h_{3}$. The temperature of state 3 is fixed by its enthalpy, pressure, and composition, and it can be determined from the property data subroutines as follows. 


$$
\begin{gathered}
T_{3}=\operatorname{TH}\left(x_{3}, h_{3}, P_{3}\right) \text { if } T_{3}<\operatorname{TSAT}\left(x_{3}, P_{3}\right) \\
T Q\left(x_{3}, P_{3}, h_{3}, q_{3}\right) \text { otherwise }
\end{gathered}
$$

This value of $T_{3}$ is then used with equations 2.2 .9 and 2.2 .10 to determine the rate of heat transfer. The difference between this result and that obtained from equation 2.2 .11 is used to find an improve value of $T_{6}\left(=T_{13}\right)$ by the Secant method. (1)

\subsection{SOLUTION - COOLED ABSORBER}

SUBROUTINE ABSSC

PARAMETERS :

1. (UA) abss - overall heat conductance

INPUTS: Streams 3,11, 14

OUTPUTS: Streams 4,12

Absorption of refrigerant in the ARKLA unit occurs in two components; a solution-cooled and an air-cooled absorber. In the solution-cooled absorber, the hot weak (in refrigerant) solution from the generator is sprayed over a coil containing the cooler rich solution which is thereby preheated before it enters the generator during this process. The refrigerant vapor is partially absorbed in the weak solution. It is also entrained so that a two-phase solution exits the absorber at state 12 .

Mass balances require that

$$
\begin{aligned}
& \dot{\mathrm{m}}_{4}=\dot{\mathrm{m}}_{3} \\
& \mathrm{x}_{4}=\mathrm{x}_{3} \\
& \dot{\mathrm{m}}_{12}=\dot{\mathrm{m}}_{11}+\dot{\mathrm{m}}_{14} \\
& \dot{\mathrm{m}}_{12} \mathrm{x}_{12}=\dot{\mathrm{m}}_{11} \mathrm{x}_{11}+\dot{\mathrm{m}}_{14} \mathrm{x}_{14}
\end{aligned}
$$

Pressure losses are neglected.

$$
\begin{aligned}
& \mathrm{P}_{4}=\mathrm{P}_{3} \\
& \mathrm{P}_{12}=\mathrm{P}_{11}
\end{aligned}
$$

The rate of heat transfer between the stream flowing in the coil and the absorbent is expressed in terms of an overall heat conductance and a $10 g$ mean temperature difference.

$$
\dot{\mathrm{Q}}=(\mathrm{UA}) \text { abss } \Delta \mathrm{T}_{1 \mathrm{~m}}
$$


where

$$
\Delta T_{1 \mathrm{~m}}=\frac{\left(\mathrm{T}_{14}-\mathrm{T}_{4}\right)-\left(\mathrm{T}_{12}-\mathrm{T}_{3}\right)}{\ln \left(\frac{\mathrm{T}_{14}-\mathrm{T}_{4}}{\mathrm{~T}_{12}-\mathrm{T}_{3}}\right)}
$$

Energy balances require that

$$
\dot{\mathrm{Q}}=\dot{\mathrm{m}}_{3}\left(\mathrm{~h}_{4}-\mathrm{h}_{3}\right)=\dot{\mathrm{m}}_{11} \mathrm{~h}_{11}+\dot{\mathrm{m}}_{14} \mathrm{~h}_{14}-\dot{\mathrm{m}}_{12} \mathrm{~h}_{12}
$$

Equations 2.3.7 through 2.3.9 must be solved iteratively for $\mathrm{T}_{4}$ and $\mathrm{T}_{12}$. A guess is made for $\mathrm{T}_{4}$. The enthalpy at state 4 is then obtained from property data routines. If the guess value of $\mathrm{T}_{4}$ is less than the saturation temperature, stream 4 is subcooled. In this case

$$
\begin{aligned}
& \mathrm{h}_{4}=\operatorname{HL}\left(\mathrm{x}_{4}, \mathrm{~T}_{4}, \mathrm{P}_{4}\right) \text { for } \mathrm{T}_{4}<\operatorname{TSAT}\left(\mathrm{x}_{4}, \mathrm{P}_{4}\right) \\
& \mathrm{q}_{4}=0
\end{aligned}
$$

For two-phase conditions $\left(\mathrm{T}_{4}>\operatorname{TSAT}\left(\mathrm{x}_{4}, \mathrm{P}_{4}\right)\right)$,

$$
\begin{aligned}
& x_{4}^{L}=\operatorname{XLPT}\left(P_{4}, T_{4}\right) \\
& x_{4}^{V}=X V\left(x_{4}^{L}, P_{4}\right) \\
& h_{4}^{L}=H L\left(x_{4}^{L}, T_{4}, P_{4}\right) \\
& h_{4}^{V}=H V\left(x_{4}^{L}, x_{4}^{V}, T_{4}, P_{4}\right) \\
& q_{4}=\left(x_{4}-x_{4}^{L}\right) /\left(x_{4}^{V}-x_{4}^{L}\right) \\
& h_{4}=\left(1-q_{4}\right) h_{4}^{L}+q_{4} h_{4}^{V}
\end{aligned}
$$

The enthalpy of state 12 and rate of heat transfer can now be evaluated from equation 2.3.9. The temperature and quality of state 12 are fixed by the pressure, overall composition and enthalpy of the mixture and can be determined from property data routine $T Q$.

$$
T_{12}=T Q\left(x_{12}, P_{12}, h_{12}, q_{12}\right)
$$

The rate of heat transfer can now be calculated from equations 2.3 .7 and 2.3.9. The difference between the values of $Q$ calculated from equations 2.3 .7 and 2.3.9 is used to find an improved value of $\mathrm{T}_{4}$ by the Secant method. The iterations are terminated when two successive values of $\mathrm{T}_{4}$ are within a specified tolerance. 


\subsection{AIR-COOLED ABSORBER}

\section{SUBROUTINE CONABS}

This subroutine is used for evaluating the performance of the air-cooled absorber as well as for the condenser as outlined below.

\section{PARAMETERS :}

1. (UA) absa - overall heat conductance

2. Tair - air temperature

INPUTS: Stream 12

OUTPUTS: Stream 1, $\dot{Q}_{\text {absa }}$

A two-phase mixture enters the air-cooled absorber and it is cooled (and condensed) by heat transfer to the air stream. Continuity requires that

$$
\begin{aligned}
& \dot{\mathrm{m}}_{1}=\dot{\mathrm{m}}_{12} \\
& \mathrm{x}_{1}=\mathrm{x}_{12}
\end{aligned}
$$

Pressure losses are neglected.

$$
P_{1}=P_{12}
$$

The rate of heat transfer between the solution and the air is expressed using a log-mean temperature difference relation.

$$
\dot{\mathrm{Q}}_{\mathrm{absa}}=(\mathrm{UA})_{\mathrm{absa}} \Delta \mathrm{T}_{1 \mathrm{~m}}
$$

where

$$
\Delta \mathrm{T}_{1 \mathrm{~m}}=\frac{\mathrm{T}_{12}-\mathrm{T}_{1}}{\ln \left(\frac{\mathrm{T}_{12}-\mathrm{T}_{\text {air }}}{\mathrm{T}_{1}-\mathrm{T}_{\text {air }}}\right)}
$$

An energy balance requires that

$$
\dot{Q}_{\text {absa }}=\left(h_{12}-h_{1}\right) \dot{m}_{1}
$$

Equation 2.4.4 through 2.4 .6 are solved iteratively. A guess is made for $\mathrm{T}_{1}$ and $Q_{\text {absa }}$ is evaluated with equation 2.4.4. The enthalpy of state 1 can also be found using the assumed temperature. If state $l$ is subcooled then

$$
\begin{aligned}
& \mathrm{h}_{1}=\operatorname{HL}\left(\mathrm{x}_{1}, \mathrm{~T}_{1}, \mathrm{P}_{1}\right) \text { for } \mathrm{T}_{1}<\operatorname{TSAT}\left(\mathrm{x}_{1}, \mathrm{P}_{1}\right) \\
& \mathrm{q}_{1}=0
\end{aligned}
$$

If state 1 is two-phase then $T_{1} \geq \operatorname{TSAT}\left(\mathrm{x}_{1}, \mathrm{P}_{1}\right)$ and 


$$
\begin{aligned}
& x_{1}^{L}=\operatorname{XLPT}\left(P_{1}, T_{1}\right) \\
& x_{1}^{V}=\operatorname{XV}\left(x_{1}^{L}, P_{1}\right) \\
& h_{1}^{L}=H L\left(x_{1}^{L}, T_{1}, P_{1}\right) \\
& h_{1}^{V}=H V\left(x_{1}^{L}, x_{1}^{V}, T_{1}, P_{1}\right) \\
& q_{1}=\left(x_{1}-x_{1}^{L}\right) /\left(x_{1}^{V}-x_{1}^{L}\right) \\
& h_{1}=\left(1-q_{1}\right) h_{1}^{L}+q_{1} h_{1}^{V}
\end{aligned}
$$

Qabsa can now be calculated from equation 2.4.6. The difference between this result and the value of Qabsa found from equation 2.4 .4 is used to find an improved value of $\mathrm{T}_{1}$ by the Secant method.

\subsection{GENERATOR}

SUBROUTINE GEN

PARAMETERS :

1. $\dot{Q}_{g e n}$ - rate of heat input

2. $\varepsilon_{\mathrm{L}}$ - heat transfer effectiveness between the exiting weak solution and the entering rich solution

3. $\varepsilon_{V}$ - heat transfer effectiveness between the exiting vapor and the entering rich solution

INPUTS: Streams 4,13

OUTPUTS: Streams 5,14

Refrigerant is separated from the absorbent by the heat input to the generator. The high pressure of the boiling refrigerant forces the weak solution at the lower part of the generator through a pipe leading to the solution-cooled absorber. In the ARKLA unit, the pipe is arranged so that the weak solution is placed in a heat exchange situation with the entering rich solution. Similarly, heat exchange occurs between the exiting vapor, and the incoming rich solution.

Mass balances yield

$$
\begin{aligned}
& \dot{\mathrm{m}}_{5}+\dot{\mathrm{m}}_{14}=\dot{\mathrm{m}}_{4}+\dot{\mathrm{m}}_{13} \\
& \dot{\mathrm{m}}_{5} \mathrm{x}_{5}+\dot{\mathrm{m}}_{14} \mathrm{x}_{14}=\dot{\mathrm{m}}_{4} \mathrm{x}_{4}+\dot{\mathrm{m}}_{13} \mathrm{x}_{13}
\end{aligned}
$$

Pressure losses are neglected

$$
\mathrm{P}_{5}=\mathrm{P}_{14}=\mathrm{P}_{4}=\mathrm{P}_{13}
$$


Internal heat exchanges between the incoming rich solution and the exiting streams are described in terms of effectiveness factors. For the exiting vapor,

$$
\mathrm{T}_{5}=\mathrm{T}_{\text {gen }}-\varepsilon_{\mathrm{V}}\left(\mathrm{T}_{\text {gen }}-\mathrm{T}_{4}\right)
$$

and for the exiting weak solution,

$$
\mathrm{T}_{14}=\mathrm{T}_{\text {gen }}-\varepsilon_{\mathrm{L}}\left(\mathrm{T}_{\text {gen }}-\mathrm{T}_{4}\right)
$$

where $\mathrm{T}_{\text {gen }}$ is the temperature of the weak solution at the lower part of the generator where it enters the pipe.

An energy balance around the generator requires that

$$
\dot{\mathrm{m}}_{5} \mathrm{~h}_{5}+\dot{\mathrm{m}}_{14} \mathrm{~h}_{14}=\dot{\mathrm{m}}_{13} \mathrm{~h}_{13}+\dot{\mathrm{m}}_{4} \mathrm{~h}_{4}+\dot{\mathrm{Q}}_{\text {gen }}
$$

The above equations are solved iteratively. A guess is made for $T_{g e n}$. The concentration (at equilibrium) of the weak solution is thus established.

$$
\mathrm{x}_{14}=\operatorname{XLPT}\left(\mathrm{P}_{14}, \mathrm{~T}_{\text {gen }}\right)
$$

The temperatures of the exiting streams are determined from equations 2.5 .4 and 2.5.5. These temperatures are used to determine the specific enthalpies of the exiting streams and the composition of the vapor.

$$
\begin{aligned}
\mathrm{h}_{14} & =\mathrm{HL}\left(\mathrm{x}_{14}, \mathrm{~T}_{14}, \mathrm{P}_{14}\right) \\
\mathrm{x}_{5} & =\operatorname{XV}\left(\mathrm{x}_{5}^{\mathrm{L}}, \mathrm{P}_{5}\right) \\
\mathrm{h}_{5} & =\operatorname{HV}\left(\mathrm{x}_{5}^{\mathrm{L}}, \mathrm{x}_{5}, \mathrm{~T}_{5}, \mathrm{P}_{5}\right)
\end{aligned}
$$

where $x_{5}^{L}=\operatorname{XLPT}\left(P_{5}, T_{5}\right)$

With the concentrations of the exiting streams determined, equations 2.5 .1 and 2.5.2 are used to determine the mass flow rates, which are then used with the calculated enthalpies in equation 2.5.6. The difference between the left and right hand sides of equation 2.5 .6 is used to find an improved value of $\mathrm{T}_{\text {gen }}$ by the secant method. The iterations are terminated when two successive values of $\mathrm{T}_{\text {gen }}$ are within a specified tolerance.

\subsection{CONDENSER}

SUBROUTINE CONABS

PARAMETERS :

1. (UA) cond - overall heat conductance

2. Tair - air temperature 


\section{INPUTS: Stream 6}

OUTPUTS: Stream $7, \dot{Q}_{\text {cond }}$

Rerigerant vapor, along with a small amount of water is condensed and possibly subcooled in the condenser.

Continuity requires that

$$
\begin{aligned}
& \dot{\mathrm{m}}_{7}=\dot{\mathrm{m}}_{6} \\
& \mathrm{x}_{7}=\mathrm{x}_{6}
\end{aligned}
$$

Pressure losses are neglected

$$
\mathrm{P}_{7}=\mathrm{P}_{6}
$$

The heat transfer rate between the refrigerant and the air is expressed using a log-mean temperature difference relation.

$$
\dot{\mathrm{Q}}_{\text {cond }}=(\mathrm{UA})_{\text {cond }} \Delta \mathrm{T}_{1 \mathrm{~m}}
$$

where

$$
\Delta T_{1 \mathrm{~m}}=\frac{\mathrm{T}_{6}-\mathrm{T}_{7}}{\ln \left(\frac{\mathrm{T}_{6}-\mathrm{T}_{\text {air }}}{\mathrm{T}_{7}-\mathrm{T}_{\text {air }}}\right.}
$$

An energy balance requires that

$$
\dot{\mathrm{Q}}_{\text {cond }}=\left(\mathrm{h}_{6}-\mathrm{h}_{7} \dot{\mathrm{m}}_{7}\right.
$$

The heat transfer processes occurring in the condenser are identical to those in the air-cooled absorber. As a result, the same subroutine is used for both components. The program logic is described in section 2.4 .

\subsection{REFRIGERANT HEAT EXCHANGER}

SUBROUTINE HXLV

PARAMETERS :

1. (UA) $)_{\mathrm{hx}}$ - overall heat conductance

INPUTS : Streams 7,10

OUTPUTS: Streams 8,11 
Liquid refrigerant from the condenser is cooled further in the refrigerant heat exchanger by the refrigerant vapor leaving the evaporator. Mass balances require that

$$
\begin{aligned}
& \dot{\mathrm{m}}_{8}=\dot{\mathrm{m}}_{11}=\dot{\mathrm{m}}_{7}=\dot{\mathrm{m}}_{10} \\
& \mathrm{x}_{8}=\mathrm{x}_{11}=\mathrm{x}_{7}=\mathrm{x}_{10}
\end{aligned}
$$

Pressure losses are neglected

$$
\mathrm{P}_{8}=\mathrm{P}_{11}=\mathrm{P}_{7}=\mathrm{P}_{10}
$$

The rate of heat exchange between the streams entering and exiting the evaporator is expressed

$$
\dot{\mathrm{Q}}_{\mathrm{hx}}=(\mathrm{UA})_{\mathrm{hx}} \frac{\left(\mathrm{T}_{8}-\mathrm{T}_{10}\right)-\left(\mathrm{T}_{7}-\mathrm{T}_{11}\right)}{\ln \left(\frac{\mathrm{T}_{8}-\mathrm{T}_{10}}{\mathrm{~T}_{7}-\mathrm{T}_{11}}\right)}
$$

Also, an energy balance requires that

$$
\dot{\mathrm{Q}}_{\mathrm{hx}}=\left(\mathrm{h}_{11}-\mathrm{h}_{10}\right) \dot{\mathrm{m}}_{10}=\left(\mathrm{h}_{8}-\mathrm{h}_{7}\right) \dot{\mathrm{m}}_{7}
$$

Equations 2.7.4 and 2.7.5 are solved iteratively. A guess is made for $\mathrm{T}_{8}$, which establishes the enthalpy of $\mathrm{T}_{8}$.

$$
\mathrm{h}_{8}=\mathrm{HL}\left(\mathrm{x}_{8}, \mathrm{~T}_{8}, \mathrm{P}_{8}\right)
$$

The enthalpy of state 11 is then directly determined from equation 2.7 .5 which establishes its temperature and quality.

$$
\mathrm{T}_{11}=\mathrm{TQ}\left(\mathrm{x}_{8}, \mathrm{P}_{8}, \mathrm{~h}_{8}, \mathrm{q}_{8}\right)
$$

With $\mathrm{T}_{8}$ and $\mathrm{T}_{11}$ known, the rate of heat exchange can be calculated from equation 2.7.4. The difference in the values of $\mathrm{Qhx}_{\mathrm{hx}}$ obtained from equations 2.7.4 and 2.7.5 is used to improve the estimate of $\mathrm{T}_{8}$ using the Secant method. Iteration stops when two successive values of $\mathrm{T}_{8}$ are within a specified tolerance.

\section{$2.8 \quad$ RESTRICTOR}

SUBROUTINE THROT

PARAMETERS :

1. Pevap - low side pressure [psia]

INPUTS: Stream 8

OUTPUTS: Stream 9 
In the ARKLA chiller, the refrigerant leaving the condenser is reduced to the evaporator pressure as it passes through two refrigerent restrictors. In the model, the drop in pressure is obtained by a single restrictor. Mass and energy balances require that

$$
\begin{aligned}
& \dot{\mathrm{m}}_{9}=\dot{\mathrm{m}}_{8} \\
& \mathrm{x}_{9}=\mathrm{x}_{8} \\
& \mathrm{~h}_{9}=\mathrm{h}_{8}
\end{aligned}
$$

The restrictor outlet stream will be a two-phase mixture. The temperature and quality of this stream can be determined since its composition, pressure and enthalpy are known.

$$
T_{9}=T Q\left(x_{9}, P_{9}, h_{9}, q_{9}\right)
$$

\subsection{EVAPORATOR}

\section{PARAMETERS :}

1. (UA) evap - overall heat conductance between the evaporating refrigerant
and the chilled water

INPUTS: Streams 9,15

OUTPUTS: Streams 10,16, Q evap

In the ARKLA chiller, water is cooled as is drips over a coil through which the evaporating refrigerant flows. The refrigerant may exit the evaporator in a two-phase or superheated state.

In earlier versions of this program, the small amount of water (2-3 percent on a weight basis) with the refrigerant was neglected. It was found however, that the water has substantial effect on the evaporator performance and it must be accounted for.

Mass balances require that

$$
\begin{aligned}
& \dot{\mathrm{m}}_{10}=\dot{\mathrm{m}}_{9} \\
& \mathrm{x}_{10}=\mathrm{x}_{9} \\
& \dot{\mathrm{m}}_{16}=\dot{\mathrm{m}}_{15}
\end{aligned}
$$

Pressure losses are neglected

$$
\mathrm{P}_{10}=\mathrm{P}_{9}
$$


The rate of heat transfer between the refrigerant and the water is expressed

$$
\dot{Q}_{\text {evap }}=(\mathrm{UA})_{\text {evap }} \Delta \mathrm{T}_{1 \mathrm{~m}}
$$

where

$$
\Delta T_{1 \mathrm{Im}}=\frac{\mathrm{T}_{10}-\mathrm{T}_{9}}{\ln \left(\frac{\mathrm{T}_{15}-\mathrm{T}_{9}}{\mathrm{~T}_{15}-\mathrm{T}_{10}}\right)}
$$

The log-mean temperature difference assumes this form since the design of the evaporator causes the refrigerant at both the inlet and outlet of the evaporator to be in heat exchange contact with the entering chilled water.

An energy balance requires that

$$
\dot{Q}_{\text {evap }}=\left(h_{10}-h_{g}\right) \dot{m}_{g}=\left(h_{16}-h_{15}\right) \dot{m}_{15}
$$

Equations 2.9.5 through 2.9 .7 are solved iteratively. A guess is made for $\mathrm{T}_{10}$. The log-mean temperature difference and rate of heat transfer are then calculated from equations 2.9 .6 and 2.9 .5 , respectively.

With water present in the refrigerant, the refrigerant always exits in two-phase. Its enthalpy and quality are found as follows:

$$
\begin{aligned}
& x_{10}^{L}=\operatorname{XLPT}\left(P_{10}, T_{10}\right) \\
& x_{10}^{V}=X V\left(x_{10}^{L}, P_{10}\right) \\
& q_{10}=\left(x_{10}-x_{10}^{L}\right) /\left(x_{10}^{V}-x_{10}^{L}\right) \\
& h_{10}^{L}=H L\left(x_{10}^{L}, P_{10}\right) \\
& h_{10}^{V}=H V\left(x_{10}^{L}, x_{10}^{V}, \mathrm{~T}_{10}, P_{10}\right) \\
& h_{10}=\left(1-q_{10}\right) h_{10}^{L}+q_{10} h_{10}^{V}
\end{aligned}
$$

Using this enthalpy, the rate of heat transfer is calculated from equation 2.9.7. The difference between the values obtained from equations 2.9 .5 and 2.9 .7 is used to improve the estimate of $\mathrm{T}_{10}$ with the Secant method. Iteration is stopped when two successive values of $\mathrm{T}_{10}$ are within a specified tolerance. 


\section{EXPERIMENTAL DATA}

The steady-state performance of an ARKLA water chiller (model no. ACC 36 00) was measured in an environmental chamber at air temperatures of $80^{\circ} \mathrm{F}, 95^{\circ} \mathrm{F}$, and $100^{\circ} \mathrm{F}$. In all tests, $55^{\circ} \mathrm{F}$ water was supplied to the unit at $7.2 \mathrm{GPM}$. The test apparatus and procedures were as described by Lindsay and Didion (2) with the following modifications.

1. A micro-computer (CROMEMCO) was interfaced with the FLUKE data logger to improve the analysis of the experimental data. Temperatures were measured at 48 locations shown in figure 2 and listed in table 1 . After steadystate operation was achieved, these data were recorded at two minute intervals for 30 minutes and averaged over this period.

2. To measure the generator heat input, the $\mathrm{CO}_{2}$ and $\mathrm{O}_{2}$ content of the exiting flue gas were independently measured using a L1RA Model 300 Infrared Analyzer and a LYNN Model 6000-B Combustion Analyzer, respectively. The flue gas temperature was measured with a six-junction averaging thermocouple (location 30) and the gas usage was measured in cubic feet by a Spraque dry test meter. None of these measurements varied significantly with air temperature. Assuming the gas to be pure methane, the $\mathrm{CO}_{2}$ and $\mathrm{O}_{2}$ measurements indicate a theoretical amount of air ranging between 153 percent and 168 percent. A combustion analysis results in the generator heat input between 58100 and $58800 \mathrm{BTU} / \mathrm{h}$.

3. A sample valve was installed in the line carrying the weak solution from the generator to the absorber (approximately at the location of thermocouple 3). This valve allowed the composition of the weak solution to be determined by titrating a known mass of sample with dilute sulfuric acid of known normality.

4. To install the sample valve (and two other valves intended to improve the cyclic performance of the chiller) it was necessary to remove the ammonia. The unit was recharged in a trial and error procedure until its capacity no longer was affected by small changes in the charge. The capacities measured in the steady-state tests agreed nearly identical to within 2 percent of those reported by Lindsay and Didion. (2) The evaporator and generator pressure measured in these tests, however, differ significantly from those reported by Lindsay and Didion. Pressure gauges were calibrated directly before these tests were run.

The experimental results for the steady-state tests at $80^{\circ} \mathrm{F}, 95^{\circ} \mathrm{F}$, and $100^{\circ} \mathrm{F}$ are summarized in tables $2,3,4$, respectively. The COP appearing in these tables is the ratio of the capacity to the generator heat input; it does not account for electrical power usage nor inefficiencies in combustion. 


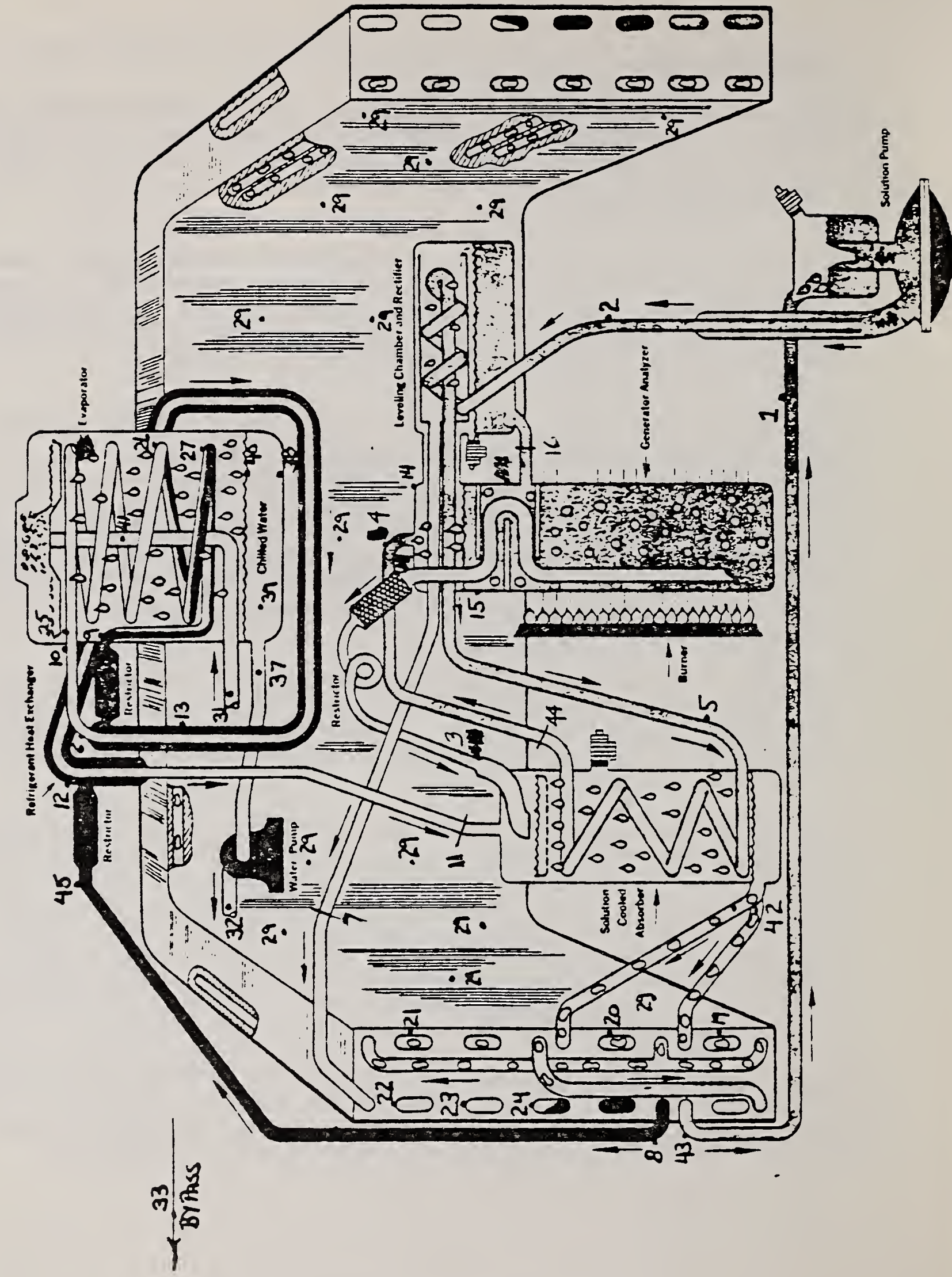

Figure 2. Thermocouple Locations. 
Table 1. ARKLA Unit, Thermocouple Locations

Chanel No.

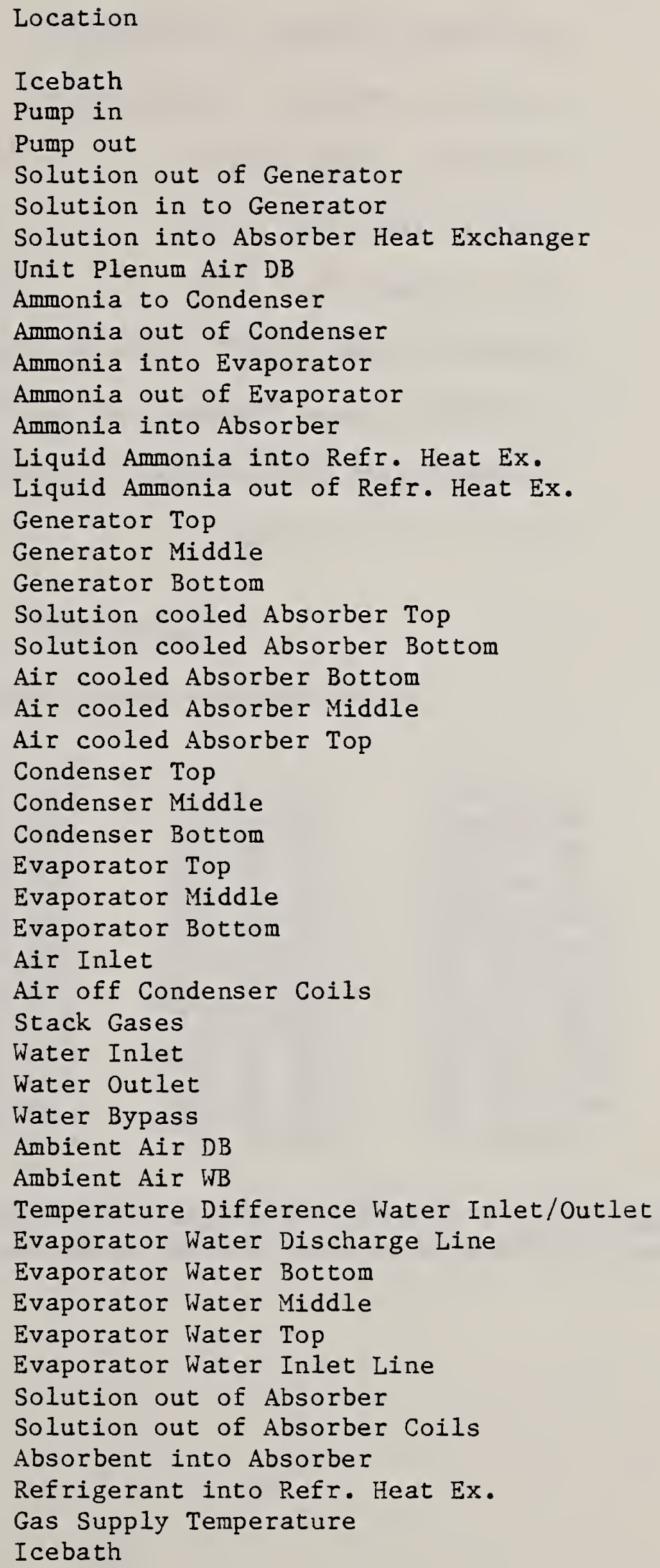


Table 2. Steady-State Test Data at $80^{\circ} \mathrm{F}$

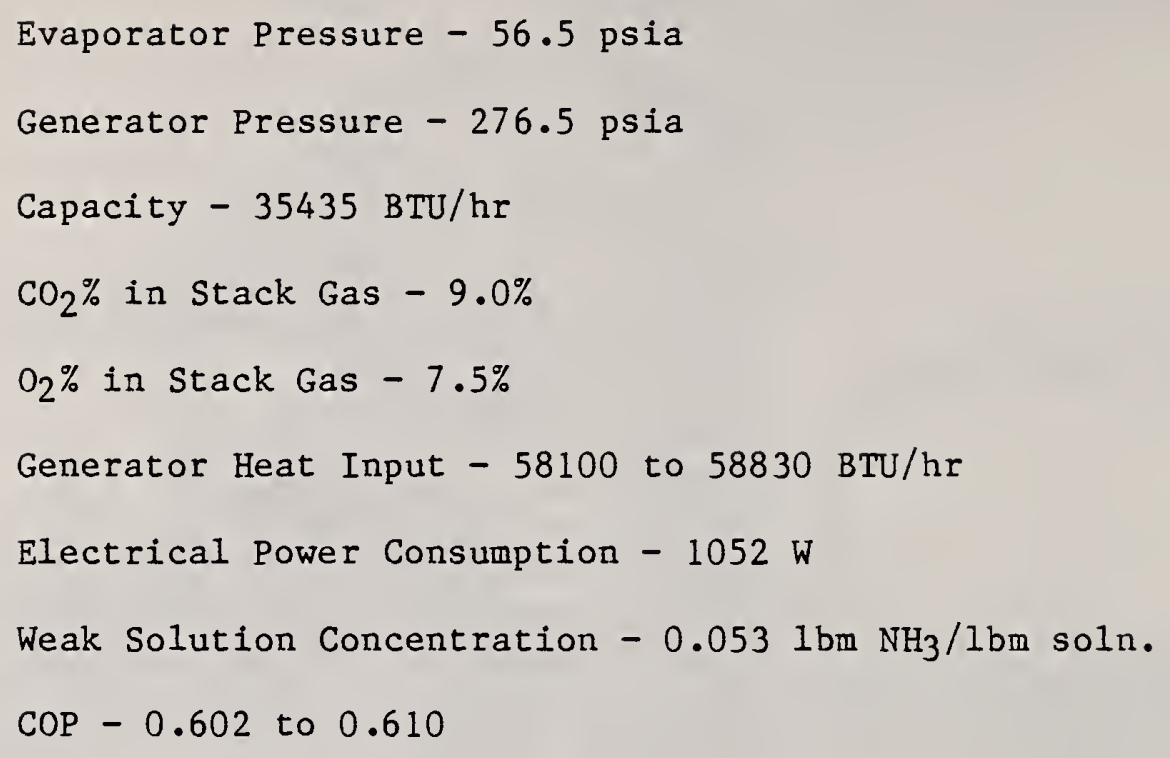

Temperatures

(Thermocouple Location $=$ Temperature $\left.{ }^{\circ} \mathrm{F}\right) *$

$\begin{array}{rrrr}0=32.49 & 1=106.16 & 2=104.20 & 3=231.54 \\ 4=220.56 & 5=139.08 & 6=57.96 & 7=181.04 \\ 8=94.92 & 9=87.43 & 10=69.21 & 11=83.46 \\ 12=94.62 & 13=79.89 & 14=219.74 & 15=235.27 \\ 16=172.29 & 17=169.98 & 18=144.41 & 19=141.91 \\ 20=139.93 & 21=124.44 & 22=121.75 & 23=118.13 \\ 24=116.99 & 25=55.18 & 26=34.46 & 27=33.07 \\ 28=79.89 & 29=123.43 & 30=446.13 & 31=55.11 \\ 32=45.21 & 33=57.46 & 34=77.73 & 35=77.93 \\ 36=3.44 & 37=44.96 & 38=43.69 & 39=40.98 \\ 40=39.94 & 41=115.92 & 42=155.96 & 43=103.98 \\ 44=218.49 & 45=96.00 & 46=72.14 & 47=32.64\end{array}$

* Channel 36 is a millivolt reading which yields the difference in temperature between the inlet and outlet chilled water when multiplied by 2.8539 . 
Table 3. Steady-State Test Data at $95^{\circ} \mathrm{F}$

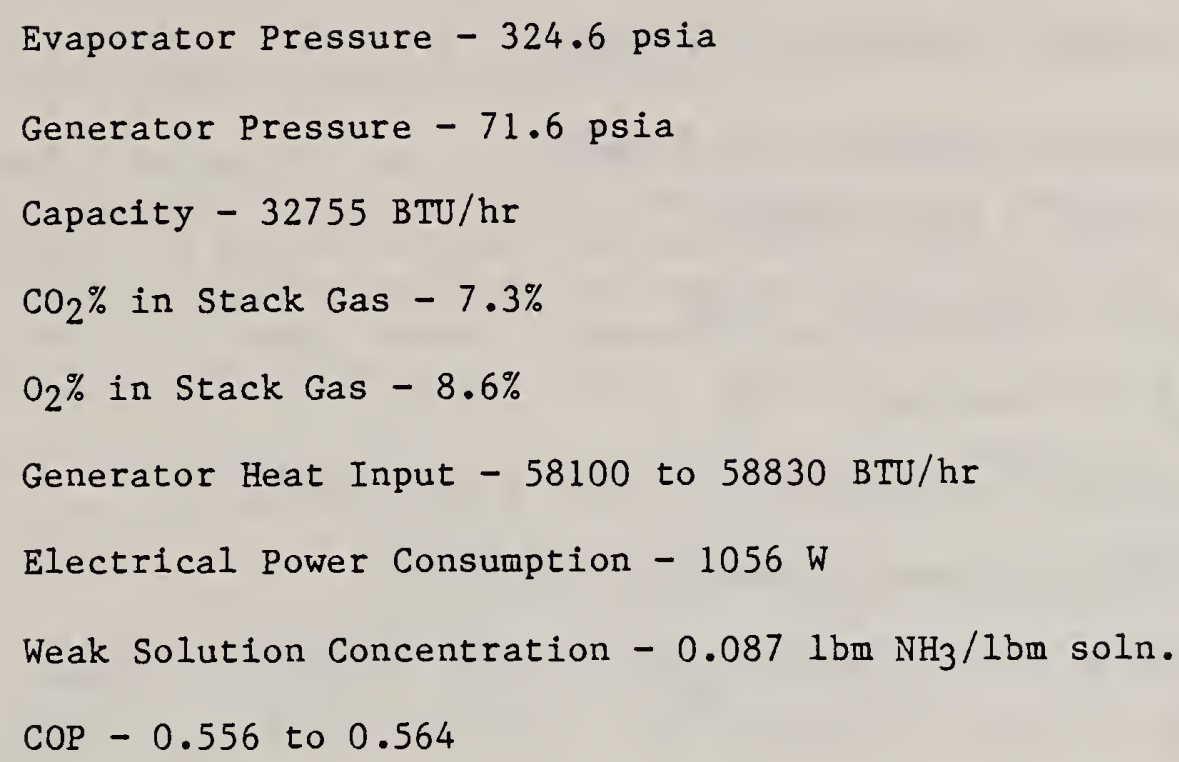

Temperatures

$\left(\right.$ Thermocouple Location $=$ Temperature $\left.{ }^{\circ} \mathrm{F}\right) *$

$\begin{array}{rrrr}0=32.32 & 1=121.64 & 2=119.60 & 3=240.57 \\ 4=230.23 & 5=152.94 & b=51.20 & 7=194.00 \\ 8=119.37 & 9=85.04 & 10=66.69 & 11=85.40 \\ 12=93.78 & 13=74.51 & 14=230.70 & 15=242.71 \\ 16=169.58 & 17=184.27 & 18=156.66 & 19=155.18 \\ 20=152.96 & 21=140.03 & 2 E=135.57 & 23=131.19 \\ 24=129.74 & 25=53.06 & 26=45.31 & 27=43.19 \\ 28=95.01 & 29=137.46 & 30=446.23 & 31=54.81 \\ 32=45.69 & 33=58.36 & 34=92.09 & 35=92.39 \\ 36=3.18 & 37=45.36 & 38=45.19 & 39=44.69 \\ 40=45.09 & 41=133.81 & 42=168.29 & 43=119.55 \\ 44=228.44 & 45=95.49 & 46=71.83 & 47=32.51\end{array}$

* Channel 36 is a millivolt reading which yields the difference in temperature between the inlet and outlet chilled water when multiplied by 2.8539 . 
Table 4. Steady-State Test Data at $100.5^{\circ} \mathrm{F}$

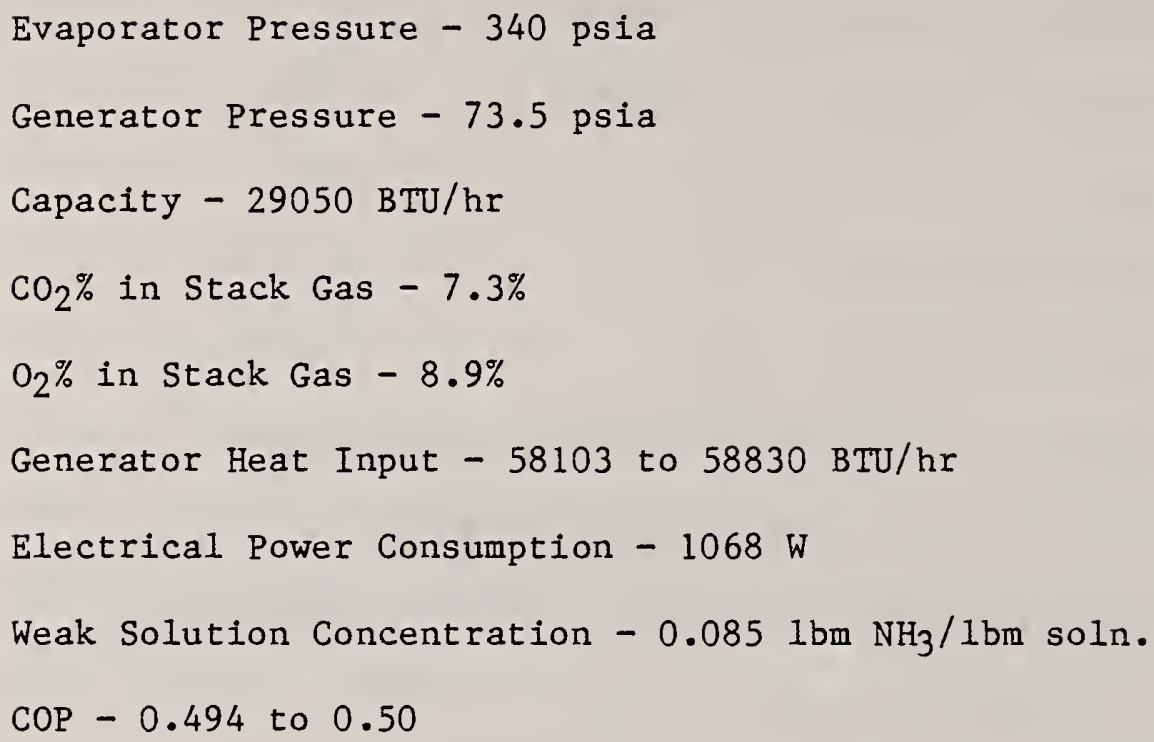

Temperatures

$\left(\right.$ Thermocouple Location $=$ Temperature $\left.{ }^{\circ} \mathrm{F}\right) *$

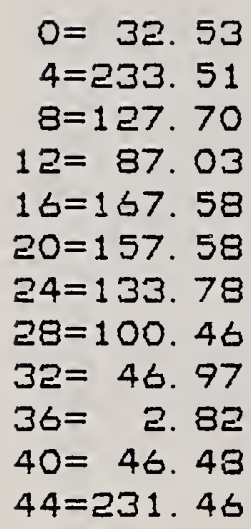

$$
\begin{array}{r}
1=126.79 \\
5=158.76 \\
9=76.66 \\
13=61.56 \\
17=189.44 \\
21=144.12 \\
25=52.36 \\
29=141.84 \\
33=59.86 \\
37=46.72 \\
41=139.23 \\
45=89.85
\end{array}
$$

$$
\begin{aligned}
2 & =125.01 \\
6 & =49.21 \\
10 & =62.50 \\
14 & =237.02 \\
18 & =157.93 \\
22 & =139.98 \\
26 & =46.83 \\
30 & =449.32 \\
34 & =98.09 \\
38 & =46.53 \\
42 & =170.58 \\
46 & =72.80
\end{aligned}
$$

$$
\begin{aligned}
3 & =247.46 \\
7 & =199 \cdot 71 \\
11 & =75.89 \\
15 & =248.13 \\
19 & =159.39 \\
23 & =135.40 \\
27 & =44.74 \\
31 & =55 \cdot 12 \\
35 & =97.97 \\
39 & =46.24 \\
43 & =124.55 \\
47 & =32.64
\end{aligned}
$$

* Channel 36 is a millivolt reading which yields the difference in temperature between the inlet and outlet chilled water when multiplied by 2.8539 . 


\section{COMPARISON OF THE MODEL TO EXPERIMENTAL DATA}

Table 5 lists the parameters which must be specified to apply the steady-state model described in section 2; also listed are the values of these parameters used in the comparisons with the experimental data.

The heat transfer parameters were selected in a trial and error process by matching the calculated and experimental temperatures and capacity. A trial and error process was needed because the effects of these parameters are interrelated; a change in any one affects the temperatures at all other points in the cycle. One set of heat transer parameters was selected for all operating conditions based on the experimental results in table 3 for $\mathrm{T}_{\text {air }}=95^{\circ} \mathrm{F}$.

The calculated performance of the cycle for a $95^{\circ} \mathrm{F}$ air temperature and these parameters values appears in table 6 . The tabular data in this table lists the location (figure 1 ), and corresponding temperature $\left(T={ }^{\circ} F\right)$, pressure $(P=p s i a)$, composition $\left(x=1 b \mathrm{NH}_{3} / \mathrm{lb} \operatorname{soln}\right)$, enthalpy $(\mathrm{H}=\mathrm{BTU} / \mathrm{lb})$ flow rate $(\mathrm{M}=1 \mathrm{~b} / \mathrm{hr})$ and quality ( $Q=1 \mathrm{~b}$ vapor/lb liquid + vapor). The last two columns give the thermocouple number in figure 2 corresponding to the locatio and the experimental temperature (TOBS $={ }^{\circ} \mathrm{F}$ ) at this point. The calculated capacity appears in the table as QEVAP in BTU/h.

As indicated previously, the heat transfer parameters in table 5 were chosen to cause the calculated temperatures, capacity, and weak solution composition to agree with the experimental data for $\mathrm{T}_{\mathrm{air}}=95^{\circ} \mathrm{F}$. The calculated capacity for this case is $32630 \mathrm{BTU} / \mathrm{h}$ which agrees well with the experimental value of $32755 \mathrm{BTU} / \mathrm{h}$ from table 3 . The calculated weak solution composition is $0.085 \mathrm{lbm} \mathrm{NH} / 1 \mathrm{bm}$ soln; the experimental value is $0.087 \mathrm{lb} \mathrm{NH} / \mathrm{bb}$ soln. The calculated and experimental temperatures in table 6 are in reasonably good agreement. However, there are significant differences in the area of the evaporator and refrigerant heat exchanger (locations 8-11). For example, location 9 is downstream of the refrigerant restrictor and the temperature at this point should be the lowest refrigerant temperature in the cycle. The experimental value, however, is $85^{\circ} \mathrm{F}$ which is clearly not possible. An investigation of thermocouple 9 revealed that it is positioned at the refrigerant restrictor, rather than downstream of the restrictor as indicated in figure 2 . A more reliable indication of the refrigerant temperature in the evaporator is provided by thermocouple 27 , which indicated $43.2^{\circ} \mathrm{F}$.

The temperature of the refrigerant exiting the evaporator (location 10) cannot be warmer than the inlet water $\left(55^{\circ} \mathrm{F}\right)$ without violating the Second Law, yet the experimental value is $66.7^{\circ} \mathrm{F}$. Thermocouple 10 was examined, calibrated with an ice bath and reinstalled with additional insulation. However, its reading did not change significantly. Perhaps the measurement is affected by conduction along the pipe.

The calculated temperature of the liquid overflow returning to the generator from the rectifier (location 13) is significantly higher than measured. It is likely, however, that the experimental value is low in this case because the overflow pipe was in an awkward location and as a result, poorly insulated. 
Table 5. Parameter Values Used in Comparisons

$$
\begin{gathered}
\dot{Q}_{\mathrm{gen}}-58460 \mathrm{BTU} / \mathrm{h} \\
\dot{\mathrm{m}}-200 \mathrm{lb} / \mathrm{h} \\
\dot{\mathrm{m}}_{\mathrm{W}}-7.2 \mathrm{gpm} \\
\mathrm{T}_{15}-55^{\circ} \mathrm{F} \\
(\mathrm{UA})_{\mathrm{rect}}-80 \mathrm{BTU} /{ }^{\circ} \mathrm{F}-\mathrm{h} \\
(\mathrm{UA})_{\mathrm{abss}}-550 \mathrm{BTU} /{ }^{\circ} \mathrm{F}-\mathrm{h} \\
(\mathrm{UA})_{\mathrm{hx}}-65 \mathrm{BTU} /{ }^{\circ} \mathrm{F}-\mathrm{h} \\
(\mathrm{UA})_{\mathrm{evap}}-3000 \mathrm{BTU} /{ }^{\circ} \mathrm{F}-\mathrm{h} \\
(\mathrm{UA})_{\mathrm{absa}}-1000 \mathrm{BTU} /{ }^{\circ} \mathrm{F}-\mathrm{h} \\
(\mathrm{UA})_{\mathrm{cond}}-750 \mathrm{BTU} /{ }^{\circ} \mathrm{F}-\mathrm{h} \\
\varepsilon_{\mathrm{L}}-0.8 \\
\varepsilon_{\mathrm{V}}-0.9
\end{gathered}
$$

$\begin{array}{ccc}\mathrm{T}_{\text {air }} & \begin{array}{l}\mathrm{P}_{\text {evap }} \\ \text { psia }\end{array} & \begin{array}{l}\mathrm{P}_{\text {gen }} \\ \text { psia }\end{array} \\ 80 & 56.5 & 275 \\ 95 & 71.6 & 325 \\ 100.4 & 73.5 & 340\end{array}$


Table 6. Calculated Results for $\mathrm{T}_{\text {air }}=95^{\circ} \mathrm{F}$

\begin{tabular}{|c|c|c|c|c|c|c|c|c|}
\hline \multicolumn{4}{|c|}{$\begin{array}{l}\text { LACK OF CLOSUFE }=\quad-20.92 \\
\text { RGEN }=58460.0 \quad \text { QEVAF }=32630.1 \\
\text { COOLING COF }=.5582\end{array}$} & \multicolumn{2}{|c|}{ QCONII $=-41703.9$} & \multicolumn{3}{|c|}{ QAES $=-49407.2$} \\
\hline LOC. & $T$ & $\mathrm{~F}$ & $x$ & $H$ & is & Q & $T C$ & TOES \\
\hline 1 & $120 \cdot 3$ & 71.6 & +436 & $-11 \cdot 3$ & $200 \cdot 0$ & .000 & 1 & 121 \\
\hline 2 & 120.3 & 325.0 & .436 & $-11 \cdot 3$ & 200.0 & .000 & 2 & 119. \\
\hline 3 & 150.3 & 325.0 & .436 & 23.3 & 200.0 & .000 & 5 & 152. \\
\hline 4 & 224.9 & 325.0 & .436 & 107.4 & 200.0 & .000 & 4 & 228 \\
\hline 5 & 240.4 & 325.0 & .941 & 661.5 & 85.3 & 1.000 & 14 & 230.7 \\
\hline 6 & 203.0 & 325.0 & .978 & 623.0 & 78.6 & 1.000 & 7 & 194.0 \\
\hline 7 & 118.7 & 325.0 & .978 & 92.8 & 78.6 & .000 & 8 & $11.9,7$ \\
\hline 8 & 83.3 & 325.0 & .978 & 53.0 & 78.6 & .000 & 13 & 71.7 \\
\hline 9 & 40.6 & 71.6 & .978 & 53.0 & 78.6 & +102 & 9 & 85. \\
\hline 10 & 47.0 & 71.6 & .978 & 468.1 & 73.6 & .854 & 10 & 66.7 \\
\hline 11 & 56.1 & 71.6 & .978 & 507.9 & 78.6 & .917 & 11 & 85. \\
\hline 12 & 180.5 & 71.6 & .436 & 235.8 & 200.0 & .260 & 42 & 168. \\
\hline 13 & 203.0 & 325.0 & .510 & 83.4 & 6.7 & .000 & 16 & 169. \\
\hline 14 & 255.9 & 325.0 & .085 & 198.2 & 121.4 & .000 & 3 & 240.6 \\
\hline 15 & 55.0 & 20.0 & .000 & 23.0 & 3610.0 & .000 & 31 & 54.8 \\
\hline 16 & 46.0 & 20.0 & .000 & 14.0 & 3610.0 & .000 & 32 & 45.7 \\
\hline
\end{tabular}


It is possible that the agreement between the calculated and measured performance could be improved by further manipulation of the heat transfer parameters.

The parameters selected for the $95^{\circ} \mathrm{F}$ air temperature test were used to calculate the cycle performance at $80^{\circ} \mathrm{F}$ and $100^{\circ} \mathrm{F}$ air temperatures; the results appear in tables 7 and 8 , respectively. The model predicts that capacity decreases with increasing air temperature, as observed experimentally. However, the calculated capacities are 3 percent high at $80^{\circ} \mathrm{F}$ and 6 percent high at $100^{\circ} \mathrm{F}$ compared to the experimental results in tables 2 and 4 . The discrepancy results from using the parameters for the $95^{\circ} \mathrm{F}$ air temperature case. The agreement between the calculated and experimental temperatures is good. As for the $95^{\circ} \mathrm{F}$ case, significant differences occur primarily in the area of the evaporator and refrigerant heat exchanger. The calculated weak solution composition changed only slightly

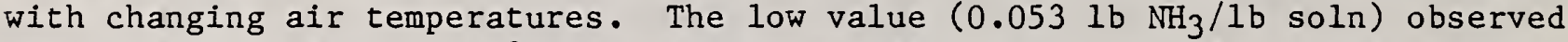
experimentally for the $80^{\circ} \mathrm{F}$ test suggests that the solution flow rate is not constant with changing air temperature as assumed. 
Table 7. Calculated Results for $\mathrm{T}_{\mathrm{air}}=80^{\circ} \mathrm{F}$

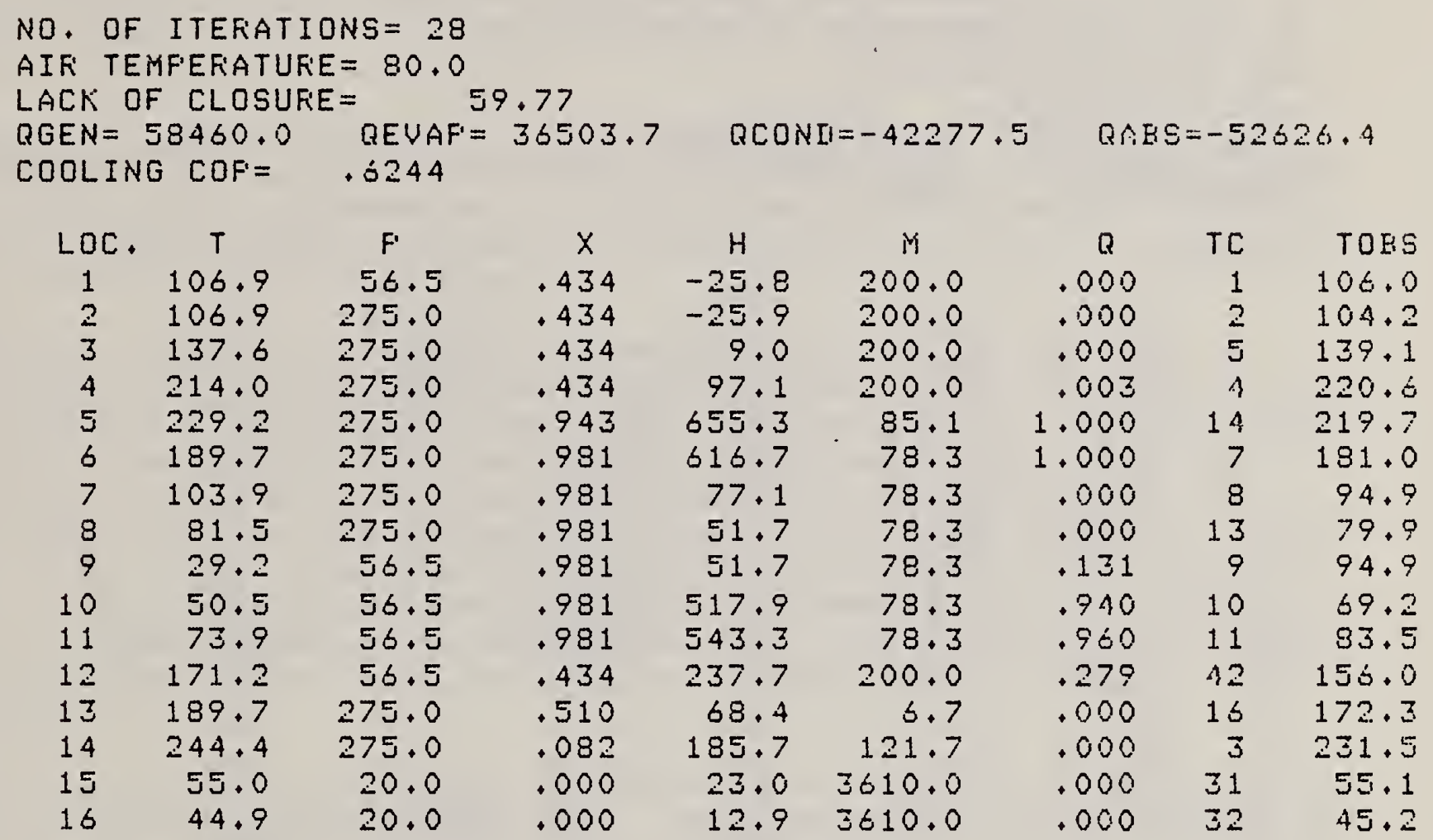


Table 8. Calculated Results for $\mathrm{T}_{\text {air }}=100.5^{\circ} \mathrm{F}$

NO. OF ITEFATIONS $=22$

AIF TEMFEFIATUFE $=100.5$

LACK OF CLOSURE $=100.07$

QGEN $=58460.0 \quad$ QEVAF $=30890.0 \quad$ QCONI $=-41613.6 \quad$ QABS $=-47636.3$ COOLING COF $=\quad .5284$

$\begin{array}{crrrrrrrr}\text { LOC. } & T & \mathrm{~T} & \mathrm{X} & \mathrm{H} & H & \mathrm{Q} & T & \text { TOES } \\ 1 & 124.7 & 73.5 & .436 & 4.3 & 200.0 & .017 & 1 & 126.8 \\ 2 & 124.7 & 340.0 & .436 & 4.3 & 200.0 & .000 & 2 & 125.0 \\ 3 & 162.2 & 340.0 & .436 & 36.7 & 200.0 & .000 & 5 & 158.8 \\ 4 & 226.0 & 340.0 & .436 & 108.7 & 200.0 & .000 & 4 & 233.5 \\ 5 & 241.9 & 340.0 & .942 & 661.7 & 85.3 & 1.000 & 14 & 237.0 \\ 6 & 207.0 & 340.0 & .977 & 625.2 & 79.1 & 1.000 & 7 & 199.7 \\ 7 & 124.6 & 340.0 & .977 & 99.1 & 79.1 & .000 & 8 & 127.7 \\ 8 & 85.5 & 340.0 & .977 & 55.0 & 79.1 & .000 & 13 & 61.6 \\ 9 & 41.9 & 73.5 & .977 & 55.0 & 79.1 & .103 & 9 & 76.7 \\ 10 & 47.0 & 73.5 & .977 & 445.8 & 79.1 & .813 & 10 & 62.5 \\ 11 & 52.1 & 73.5 & .977 & 489.9 & 79.1 & .888 & 11 & 75.9 \\ 12 & 183.4 & 73.5 & .436 & 243.1 & 200.0 & .271 & 42 & 170.6 \\ 13 & 207.0 & 340.0 & .509 & 87.8 & 6.3 & .000 & 16 & 167.6 \\ 14 & 257.8 & 340.0 & .083 & 200.8 & 121.0 & .000 & 3 & 247.5 \\ 15 & 55.0 & 20.0 & .000 & 23.0 & 3610.0 & .000 & 31 & 55.1 \\ 16 & 46.4 & 20.0 & .000 & 14.4 & 3610.0 & .000 & 32 & 47.0\end{array}$




\section{EFFECTS OF MODEL PARAMETERS}

The steady-state model described in section 2 is of limited value for interpolation or extrapolation of experimental data since it requires as input the values of the parameters listed in table 5; these parameter values must be determined from experimental data. A more detailed model would provide values for these parameters based on the physical dimensions of the components and their operating conditions. This model is, however, useful as an analysis and design tool in that the sensitivity of the heat pump performance to these design parameters can be assessed, indicating the components in the cycle for which the design is most critical.

Each of the parameters in table 5 was independently varied and the cycle performance was recalculated for the $95^{\circ} \mathrm{F}$ air temperature. The results of this sensitivity study are summarized in table 9 which lists the percent increase in capacity resulting from an increase in each parameter value from 5 percent below to 5 percent above its base value.

Relatively large sensitivities are observed to the inlet chilled water temperature $\left(\mathrm{T}_{15}\right)$ and the evaporator pressure, which affects the temperature of the evaporating refrigerant. These results indicate that, at a $95^{\circ} \mathrm{F}$ air temperature, the performance of the heat pump is constrained by the rate of heat transfer in the evaporator. This constraint becomes more apparent as the air temperature (and thus the evaporator pressure) is increased, causing a precipitous drop in capacity (as observed experimentally) between the $95^{\circ} \mathrm{F}$ and $100^{\circ} \mathrm{F}$ tests. It is unlikely that the experimental performance will be as sensitive to inlet water temperature as suggested in table 9 since the calculated result does not consider the effect the inlet water temperature will have on evaporator pressure.

The generator heat input appears to have only a small effect on capacity in the range of its base value of $58460 \mathrm{BTU} / \mathrm{h}$. Both the increase and the decrease in generator heat input resulted in a slight decrease in capacity, indicating that capacity is maximized at the base value of the generator heat input. As the generator heat input is increased, the refrigerant vapor flow rate increases, but so do the temperatures of the vapor and the weak solution. Higher temperature vapor results in a higher percentage of water in the refrigerant after rectification. The higher weak solution temperature results in less effective absorption of refrigerant. These two effects counteract the beneficial effect of increased vapor flow rate. The coefficient of performance (ratio of evaporator to generator heat inputs) is reduced 9.6 percent by the increase in generator heat input.

The solution flow rate $(\dot{m})$ has a marked effect on the weak solution composition, but its effects on the refrigerant composition and the capacity are small. From a design standpoint, it appears that little improvement in performance could be expected from using a variable speed solution pump controlled as a function of operating conditions.

The capacity decreases slightly with the increase in (UA) abss, the heat transfer conductance for the solution-cooled absorber. This non-intiutive result 
Table 9. Sensitivity of the Calculated Performance to the Design Parameters (changed from 5 percent below to 5 percent above the base values)

Variable

$\dot{Q}_{g e n}$

m

$\dot{\mathrm{m}}_{\mathrm{w}}$

$\mathrm{T}_{15}$

(UA) rect

(UA) abss

(UA) $_{h x}$

(UA) evap

(UA) absa

(UA) cond

$\varepsilon_{\mathrm{L}}$

$\varepsilon_{\mathrm{V}}$

Pevap

$\mathrm{P}_{\text {gen }}$
Base Value

$58460 \mathrm{BTU} / \mathrm{h}$

$2001 \mathrm{bm} / \mathrm{h}$

3610 gpm

$55^{\circ} \mathrm{F}$

$80 \mathrm{BTU} /{ }^{\circ} \mathrm{F}-\mathrm{h}$

$550 \mathrm{BTU} /{ }^{\circ} \mathrm{F}-\mathrm{h}$

$65 \mathrm{BTU} /{ }^{\circ} \mathrm{F}-\mathrm{h}$

$3000 \mathrm{BTU} /{ }^{\circ} \mathrm{F}-\mathrm{h}$

$1000 \mathrm{BTU} /{ }^{\circ} \mathrm{F}-\mathrm{h}$

$750 \mathrm{BTU} /{ }^{\circ} \mathrm{F}-\mathrm{h}$

0.8

0.9

71.6 psia

325 psia
$\%$ Increase

in Capacity

0.4

1.8

0

13.2

0.7

$-1 \cdot 1$

0.3

2.4

0.8

0.8

2.0

5.3

$-11.2$

0.9 
illustrates an interaction between the components. The generator is designed to allow contact between the exiting refrigerant vapor and the entering rich solution, as a result the vapor temperature approaches the rich solution temperature. This internal heat transfer improves performance since the rich solution is preheated and the water content of the refrigerant is reduced. (In the model, the temperature difference between the vapor and the rich solution is controlled by the effectiveness factor, $\varepsilon_{v}$. Capacity is relatively sensitive to this parameter.) An increase in (UA) abss increases the heat transfer rate in the solution-cooled absorber and thus the temperature of the rich solution. The increased heat transfer rate tends to increase the capacity since it increases the rate of absorption of refrigerant in the solution-cooled absorber. However, the higher rich solution temperature reduces the capacity since it causes the refrigerant vapor leaving the generator to be at a higher temperature. These competing effects indicate that there is an optimum value for (UA) abss.

Only a small increase in capacity is observed to occur as a result of increases in the heat transfer parameters. Additional heat transfer surface area would not cause a significant improvement in the steady-state performance. 


\section{CONCLUSIONS}

The usefulness of the sensitivity study in section 5 rests on the assumption that a small change in any one of the model parameters does not significantly affect any of the others. If these interaction effects can be neglected, the results of the sensitivity study reveal a number of interesting conclusions concerning the design of the ARKLA ACC-3600 chiller.

1. The unit is designed to operate at maximum capacity, rather than maximum coefficient of performance, at a $95^{\circ} \mathrm{F}$ air temperature.

2. There is an optimum heat exchanger surface area in the solution-cooled absorber.

3. Internal heat exchange between the streams entering and exiting the generator significantly improves the performance of the unit.

4. The rate at which the rich solution is pumped has only a small effect on the chiller performance. The rich solution at the pump inlet may be in two-phase under some operating conditions.

5. The chilled water inlet temperature has a significant affect on performance with higher temperatures resulting in increased capacity.

The absorption heat pump model presented here is simplistic in that pressure losses are not considered and heat transfer parameters must be supplied. In a more fundamental model, pressure losses and heat transfer coefficients would be calculated as a function of the physical characteristics of the system components and the operating conditions. Development of a model of this type would be a complex, but worthwhile project. 


\section{REFERENCES}

1. The Secant method is a modification of the Newton-Raphson iteration method in which the derivative of the function with respect to the dependent variable is found numerically.

2. Lindsay, T. M. and Didion, D. A., "Investigation of the Cyclic Performance of a Gas-Fired Absorption Chiller," NBS internal report.

3. Jain, P. C. and Gable, G. K., "Equilibrium Property Data Equations for Aqua-Ammonia Mixtures," ASHRAE Trans., 77, 149, (1971). 


\section{ACKNOWLEDGMENT}

The author is grateful to Reinhard Radermacher for his help in obtaining the experimental data and for his many suggestions concerning the model. 


\section{APPENDIX A}

\section{PROPERTY DATA ROUTINES}

Equilibrium relationships between binary mixture properties are provided by eight FORTRAN function subprograms. A brief description of the independent variables and purpose of each subprogram is as follows:

FUNCTION TSAT (XL, P)

TSAT returns the bubble point temperature of a mixture at a total pressure $P$ and a liquid refrigerant mass fraction XL.

FUNCTION XV(XL, P)

$\mathrm{XV}$ returns the mass fraction of refrigerant in the vapor phase which is in equilibrium with a liquid at total pressure $P$ and refrigerant mass fraction $X L$.

FUNCTION HL (XL, T, P)

HL returns the specific enthalpy of the liquid phase at temperature $T$, pressure $P$, and refrigerant mass fraction XL.

FUNCTION HV (XL, XV, T, P)

HV returns the specific enthalpy of the vapor phase at teperature $T$, pressure $P$, and refrigerant mass fraction XV. XL is the refrigerant mass fraction of the liquid phase in equilibrium with the vapor.

FUNCTION PSAT (XL, T, PIC)

PSAT returns the bubble point pressure of a mixture at temperature $T$ and liquid refrigerant mass fraction XL. PIC is used as the first guess in the iterative solution.

FUNCTION TH(XL, H, P, TIC)

$\mathrm{TH}$ returns the temperature of a liquid at pressure $\mathrm{P}$, refrigerant. Mass fraction XL, and specific enthalpy $H$. TIC is used as the first guess.

FUNCTION XLPT (P, T, XLIC)

XLPT returns the equilibrium refrigerant mass fraction of a liquid at pressure $P$ and temperature T. XLIC is used as the first guess in the iterative solution.

FUNCTION TQ (X, P, H, Q)

TQ returns the temperature and quality ( $Q$ ) of a two-phase mixture having an overall refrigerant mass fraction $x$ and enthalpy $H$ at a total pressure $P$. 
The property data for ammonia-water mixtures used in this report were provided by the polynomial equations of Jain and Gable (3). If a property was not given explicitly by these equations, it was found iteratively using the Secant method. 


\section{APPENDIX B}

\section{COMPUTER PROGRAM LISTING}

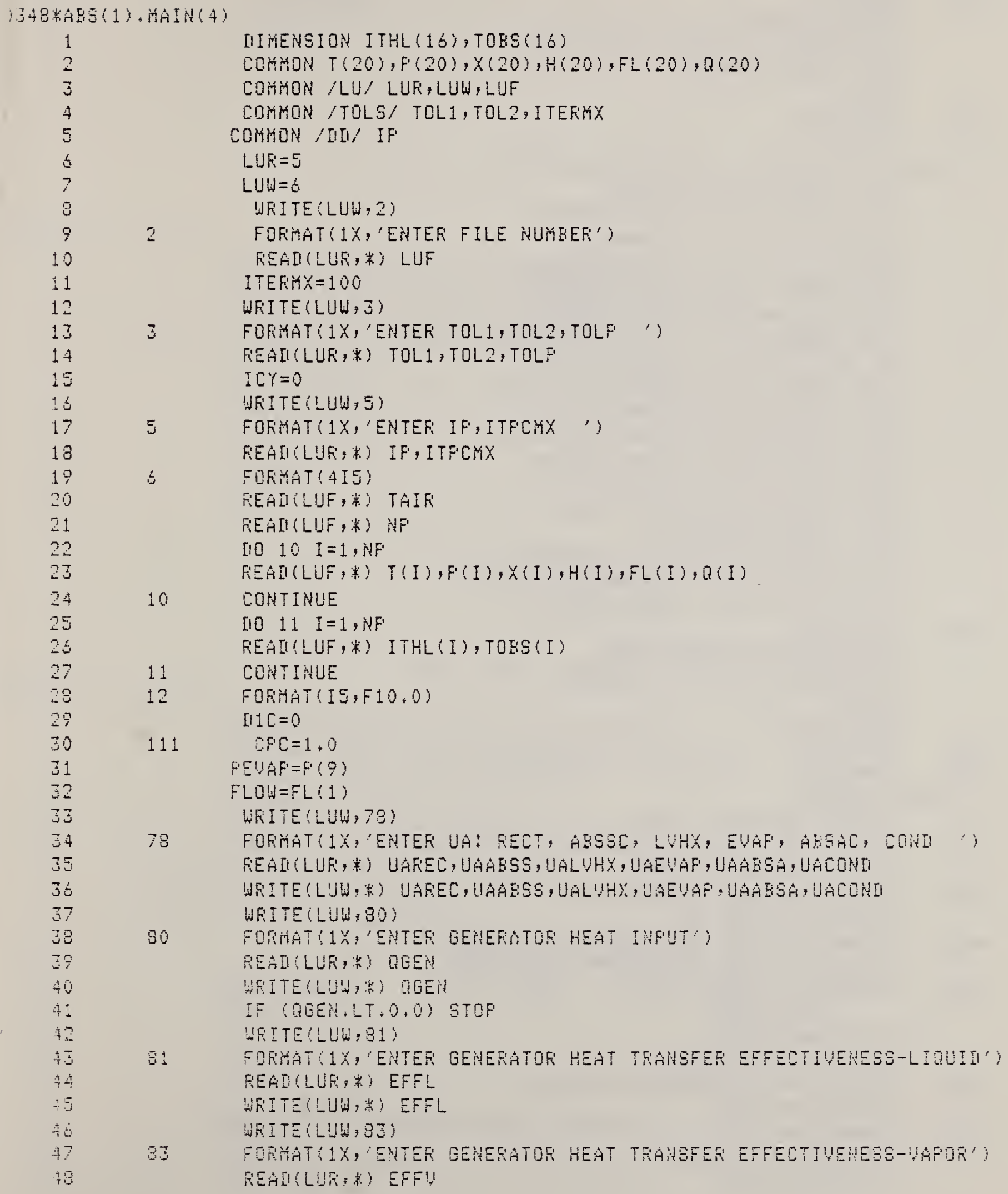

1 


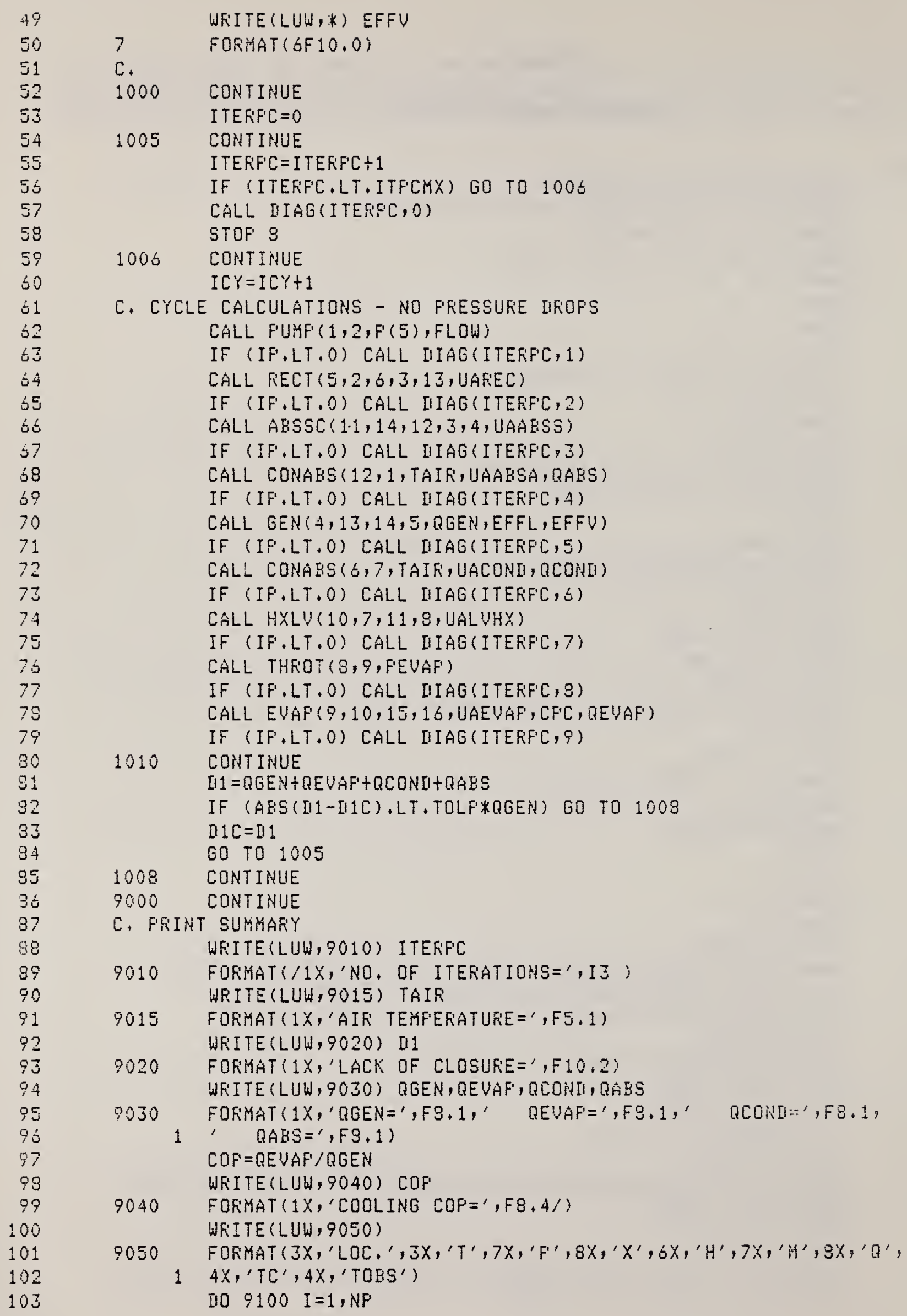

WFITE (LUW,

7 FORHAT (6F10.0)

c.

1000 CONTIHUE

ITEFIF $\mathrm{C}=0$

1005 CONTINUE

ITEF'F $C=$ ITEF'F $C+1$

IF (ITEFFC.LT.ITFCMX) GO TO 1006

CALL IIAG (ITERFC,O)

STOF 9

1006 CONTINUE

$I C Y=I C Y+1$

C. CYCLE CALCULATIONS - NO FRESSURE IIFIOFS

CALL FUHF' $\left(1,2, F^{\prime}(5), F L O W\right)$

IF (IF,LT, 0) CALL IIIAG (ITEFF'C,1)

CALL FECT $(5,2,6,3,13$, UAFEC)

IF (IF'.LT.0) CALL IIIAG (ITEFF'C, 2)

CALL AESSC $(1.1,14,12,3,4$, UAAESS)

IF (IF',LT, O) CALL IIIAG (ITEF'C, 3 )

CALL CONABS 12,1 , TAIR, UAAESA, QABS)

IF (IF, LT, O) CALL IIIAG (ITEFF'C,A)

CALL GEN(4,13,14,5, QGEN, EFFL, EFFV)

IF (IF.LT.O) CALL IIAG (ITEFFC,5)

CALL CONABS $(6,7$, TAIF', UACONI, QCONII)

IF (IF.LT.0) CALL IIIAG (ITEFF'C, 6$)$

CALL HXLU $(10,7,11,8$, UALUHX)

IF (IF',LT.0) CALL IIIAG (ITERFC, 7)

CALL THFOT $(3,9, F E U A F)$

IF (IF'LT, 0) CALL IIIAG ITERF'C,B)

CALL EVAF $(9,10,15,16$, UAEVAF', CFC, QEVUA')

IF (IF'LT,0) CALL IIIAG (ITERF', ')

1010 CONTINUE

III = RGEN+REVAF'+QCONII+RAES

IF (ABS(II1-IIIC),LT, TOLF*QGEP) GO TO 1008

DIC $=$ III

GO TO 1005

1008 CONTINUE

9000 CONTINUE

C. FIIINT SUHMARYY

WFITE (LUW, 9010) ITEFFC

9010 FOFMAT $/ 1 X, ' N O$. OF ITERATIONS=', IJ ;

WRITE (LUH, 9015) TAIR

9015 FOKINAT $\left(1 X,{ }^{\prime}\right.$ AIF' TEMF'EF'ATURE=',F5.1)

WFITE (LUW,9020) [I1

9020 FORMAT (1X,'LACK OF CLOSURE $=$, F10.2)

WFITE (LUW, 9030) QGEN, QEVAF', RCONI, QABS

9030 FOFMAT $\left(1 X,{ }^{\prime}\right.$ QGEN $=\prime, F 3.1, '$ QEVAF' $=$, FQ.1,' QCONI:=',FB.1,

, $\left.Q A B S={ }^{\prime}, F 3.1\right)$

COF $=$ QEUAF $/$ RGEN

WRITE(LUW, 9040) COF

9040 FOF'MAT $(1 X, '$ COOLING CQP $=\prime, F 8,4 /$ )

WRITE (LUW, 9050)

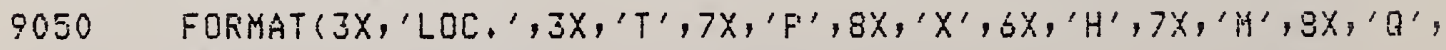

$14 X,{ }^{\prime} T C^{\prime}, 4 X{ }^{\prime},{ }^{\prime}$ TOBS')

I0 $\% 100 \quad I=1, N P$ 


\begin{tabular}{|c|c|c|}
\hline 21 & 100 & $F 1=F$ \\
\hline 22 & & $T 2=T 1+2$ \\
\hline 23 & 110 & $T T=T 2$ \\
\hline 24 & & ASSIGN 120 TO I JF \\
\hline 25 & & EO TO 800 \\
\hline $\begin{array}{l}26 \\
27\end{array}$ & 120 & $\begin{array}{l}F 2=F \\
I T E F=I T E F+1\end{array}$ \\
\hline $\begin{array}{l}28 \\
29\end{array}$ & & $\begin{array}{l}\text { IF (ITEF, LT, ITERMX) GO TO } 150 \\
\text { WFITE(LUH,130) T(JL1), QX, [ITLH,H(JL1), X(JU) }\end{array}$ \\
\hline 30 & 130 & 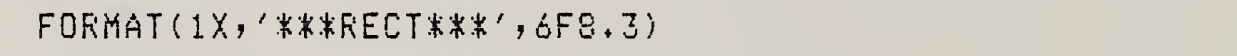 \\
\hline $\begin{array}{l}31 \\
32\end{array}$ & 150 & $\begin{array}{l}\text { STOF } \\
\text { CONTINUE }\end{array}$ \\
\hline 33 & & $T(J W)=T_{2}-F_{2} /\left(F_{2}-F_{1}\right) *\left(T_{2}-T_{1}\right)$ \\
\hline 34 & & IF (AES(T $(J U)-T 2), L T, T O L 1)$ FETURIV \\
\hline 35 & & $F_{1}=F_{2}$ \\
\hline $3 \div$ & & $T 1=T_{2}$ \\
\hline 37 & & $T 2=T(J U)$ \\
\hline 38 & & Go TO 110 \\
\hline 39 & 800 & CONT INUE \\
\hline$\div 0$ & & $T(J L 2)=T T$ \\
\hline 41 & & $X(J L 2)=X L F T(F(J L 2), T(J L 2), X(J L 2))$ \\
\hline 42 & & $X(J \cup)=X \cup(X(J L 2), F(J V))$ \\
\hline 43 & & $F L(J U)=F L(I \cup) *(X(I U)-X(J L 2)) /(X(J U)-X(J L 2))$ \\
\hline 44 & & $F L(J L 2)=F L(I \cup)-F L(J U)$ \\
\hline 45 & & $H(J U)=H V(0,7, X(J U), T T, F(J U))$ \\
\hline $4 \dot{3}$ & & $H(J L 2)=H L(X(J L 2), T(J L 2), F(J L 2))$ \\
\hline 47 & & $Q X=F L(J V) * H(J U)+F L(J L 2) * H(J L 2)-F L(I U) * H(I U)$ \\
\hline 48 & & $H(J L 1)=H(I L 1)-Q X / F L(I L 1)$ \\
\hline 49 & & $T H=T S A T\left(X(J L 1), F^{\prime}(J L 1)\right)$ \\
\hline 50 & & $T(J L 1)=T H(X(J L 1), H(J L 1), F(J L 1), 150)$, \\
\hline 51 & & $Q(J L 1)=0$. \\
\hline 52 & & IF $(T(J L 1), G T, T$ in $) T(J L 1)=T Q(X(J L 1), F(J L 1), H(J L 1), Q(J L 1))$ \\
\hline 53 & & IF (ICK.EQ,7) WFITE(LUW,7) TT,T(IU),TIJL1),T(IL1):QX \\
\hline $\begin{array}{l}54 \\
5: 4 \\
5 j\end{array}$ & 7 & $\begin{array}{l}\text { FOENAT }(1 X, 5 F 10,3) \\
\text { AFE }=(T(I V)-T(J L 1)) /(T T-T(I L 1))\end{array}$ \\
\hline 56 & & IF (ARG.GT.0.0) GO TO 810 \\
\hline 57 & & IITLK $=0$. \\
\hline 58 & & 60 TO 320 \\
\hline 57 & 810 & CONTINUE \\
\hline 50 & & IITLH $=(T(I V)-T(J L 1)-T T+T(I L 1)) / A L O G(A F G)$ \\
\hline $\begin{array}{l}61 \\
62\end{array}$ & 820 & $\begin{array}{l}\text { CONTINUE } \\
\text { QXXC=-UABOITLH }\end{array}$ \\
\hline 63 & & $F=Q X-Q X C$ \\
\hline 64 & & SO TO IJF \\
\hline & & ENII \\
\hline
\end{tabular}


COMHON /TOLS/ TOL1, TOL2, ITERMY

COMHON, $/ \mathrm{LII} / \mathrm{ICK}$

COMMON /LUI LUF, LUW, LUF

C. IV - VAFOF FEOM EVAFORATOR HX

C. ILI - LIQUIII FROM EENEFATOF

C. JL1 - LIQUII TO AIFI-COOLEII AESOREER

C. IL2 - LIQUIII FROH RECTIFIER

C. JL2 - LIQUIII TO GENERATOF

C.

$X(J L 2)=X(I L 2)$

$F^{\prime}(J L 2)=F^{\prime}(I L 2)$

$F L(J L 2)=F L(I L 2)$

$F L(J L 1)=F L(I U)+F L(I L 1)$

$X(J L 1)=(F L(I V))+($ W $X)+F L(I L 1) * X(I L 1)) / F L(J L 1)$

$F(J L 1)=F(I U)$

ITEF $=0$

$T 1=T(I L 2) \div 40$.

$T T=T 1$

ASSIEH 100 TO IJF

GO TO 800

$100 \quad F 1=F$

ASSIGH 120 TO I.JF

$110 \quad \mathrm{TT}=\mathrm{T} 2$

GO TO 800

$120 \quad F 2=F$

ITEF: $=I T E F+1$

IF (ITEF,LT, ITEFYYX) GO TO 150

WRITE (LUW, 130) T(JL2), QX, ITLH, XLIQ, XUAF, HLIQ, HUAF

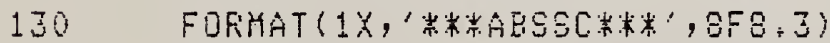

FETUENA

150 CONTIRUE

$T(U L 2)=T 2-F 2 /(F 2-F 1) *(T 2-T 1)$

IF (AES(TiJL2)-T2),LT, TOL1) RETUFI

$F 1=F 2$

$T \mathrm{~T}=\mathrm{T2}$

$T 2=T(J L 2)$

EO TO 110

300 CONTINUE

$T H=T S A T(X(J L 2), F(J L 2))$

IF (TIJL2), GT,TH) GO TO 820

810 COHTINUE

C. SUBCOOLEII LIQUIII

$H(J L 2)=H L(X(J L 2), T T, F(J L 2))$

Q $(J \operatorname{LI} 2)=0$.

GO TO 830

820 CONTINUE

C, TWD-FHASE MIXTURE

$X L I Q=X L F T(F)(J L 2): T T, 0,4)$

$X \cup A F=X \cup(X L I G, F(J L 2))$

(I) $J L 2)=(X)(J L Z)-X L I Q) /(X \cup A F-X L I Q)$

$H L I Q=H L(X L T Q, T T, F(J L Z)$

HUAF=HU(XLIQ, XUAF', TT F $(J L 2))$

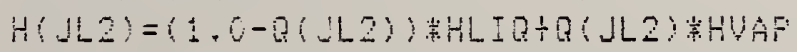

B30 CONTIVIUE 


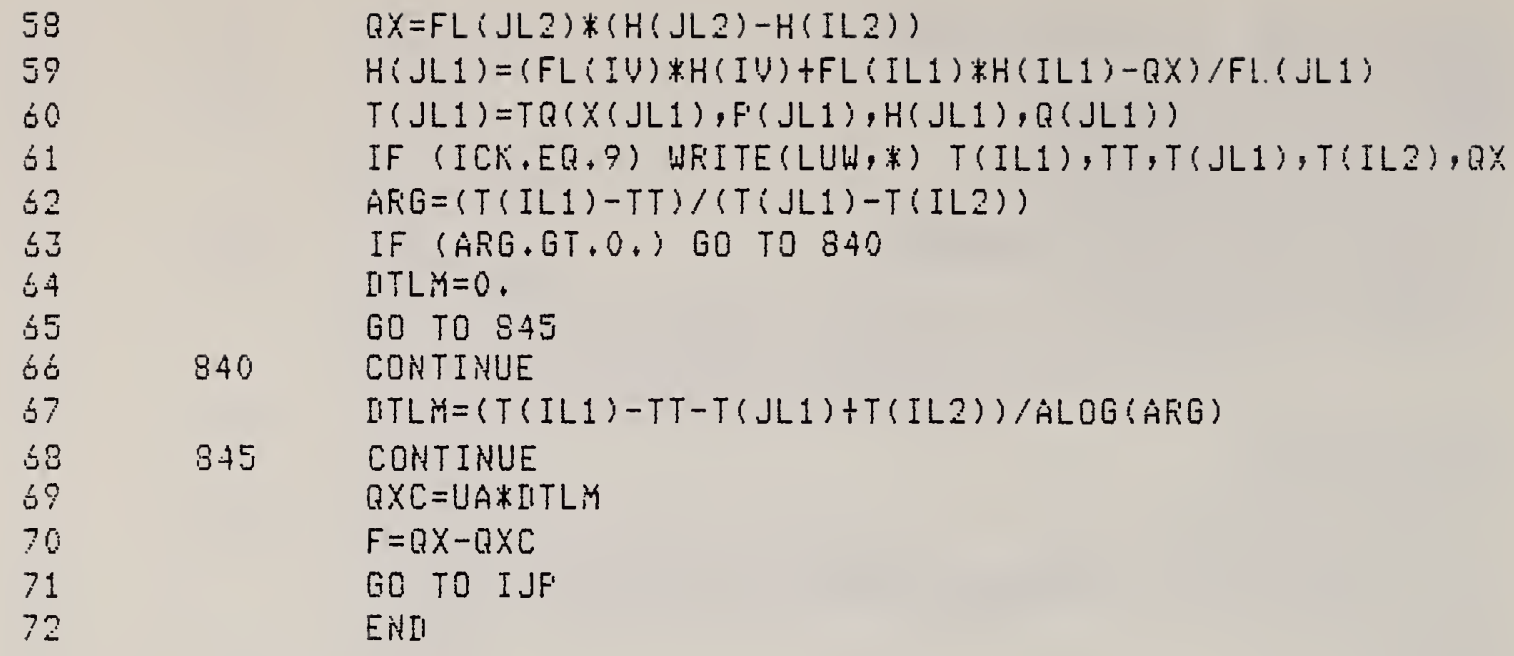

$Q X=F L(J L 2) *(H(J L 2)-H(I L 2))$

$H(J L 1)=(F L(I V) * H(I V)+F L(I L 1) * H(I L 1)-Q X) / F L(J L 1)$

$T(J L 1)=T Q(X(J L 1), F(J L 1), H(J L 1), Q(J L 1 ;)$

61

IF (ICK.EQ, 9) WRITE(LUH, *) T(IL1),TT,T(JL1),TIIL2), QX $A F G=(T(I L 1)-T T) /(T(J L 1)-T(I L 2))$

63

64

IF (ARG.GT.0.) GO TO 840

IITLM $M=0$.

GO TO 845

840 CONTINUE

bo

67

ITLH $=(T(I L 1)-T T-T(J L 1)+T(I L 2)) / A L O G(A F G)$

B45 COHTINUE

$Q \times C=U A * I T L$ H

$F=Q X-Q \times C$

70

71

72

GO TO IJF

ENII

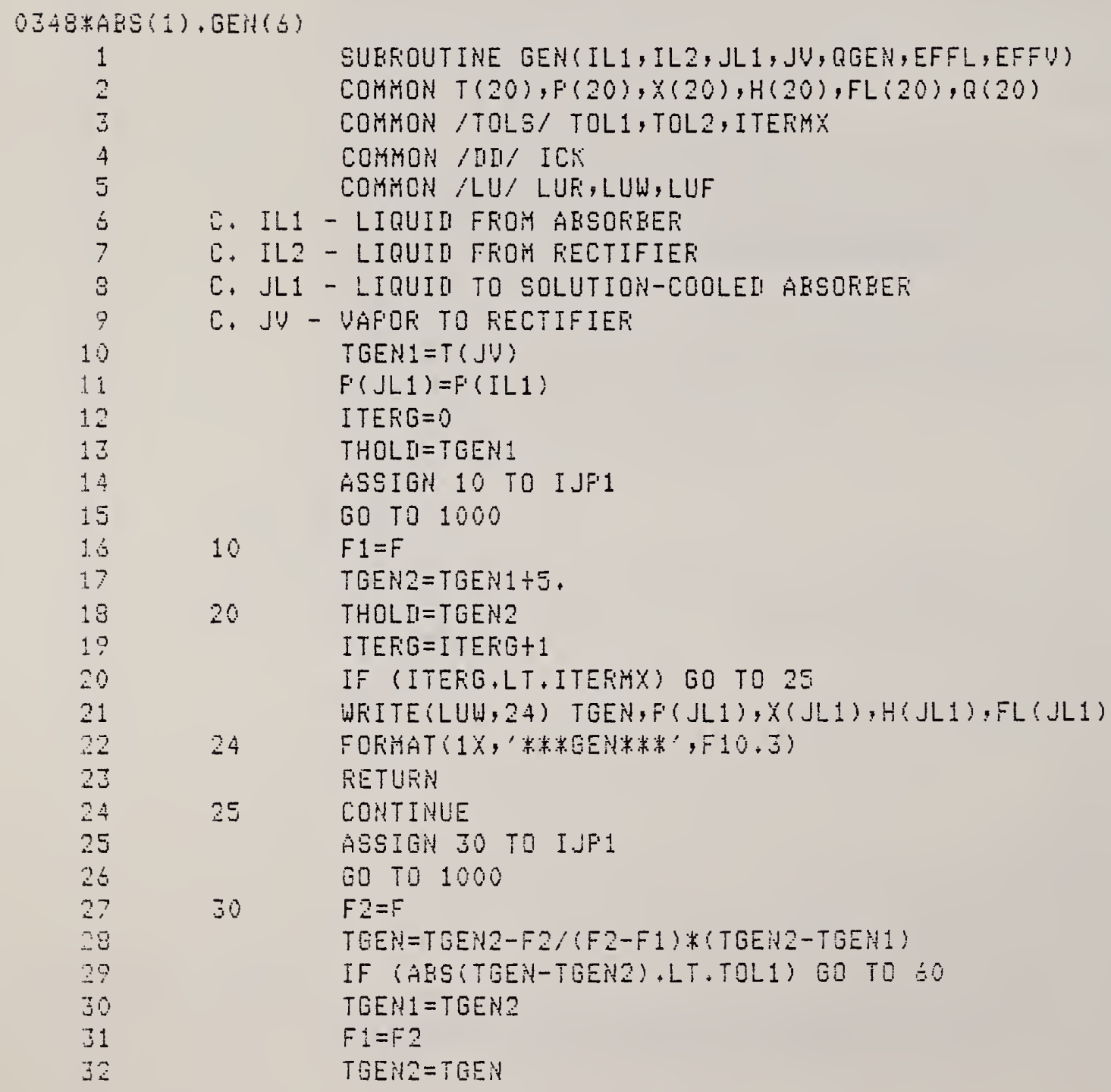

SUBROUTINE GEN(IL1, IL2, JL1, JV, QGEN, EFFL, EFFV)

COMriton $T(20), F(20), X(20), H(20), F L(20), Q(20)$

COMMON /TOLS/ TOL1, TOL2, ITEFIM

COMMON / III, ICK

COHitOH /LU/ LUF, LUW, LUF

․ IL1 - LIQUII FROH ABSOFEEF

C. IL2 - LIQUID FFOH FECTIFIER

C. JL1 - LIQUIII TO SOLUTION-COOLEII AESOFEEF:

C. JU - VAFOF: TO RECTIFIEF

TGEN $1=T(J U)$

$F^{\prime}(J L 1)=F^{\prime}(I L 1)$

ITERG $=0$

THOLII $=$ TGEN 1

ASSIGH 10 TO IJF'1

GO TO 1000

$F 1=F$

TGEN2 $=$ TGEN1+J.

20 THOLII $=$ TGEH2

ITEFG = ITEFG+1

IF (ITERG.LT.ITEENX) GO TO 25

WFITE (LUH, 24) TGEN, F $(J L 1), X(J L 1), H(J L 1), F L(J L 1)$

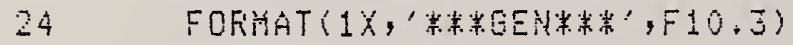

RETUEN

25 CONTINUE

AESIGH 30 TO I.JF1

60 TO 1000

$30 \quad F 2=F$

TGE $=T G E N 2-F 2 /(F 2-F 1) *(T G E N 2-T G E H 1)$

IF (AES (TGEN-TGEH2),LT.TOL1) GO TO 50

TGEH1 = TGEN2

$F 1=F 2$

TGEHA=TGEN 


\begin{tabular}{|c|c|c|}
\hline 33 & & 60 TO 20 \\
\hline 34 & 30 & CONTINUE \\
\hline 35 & & $T(J L 1)=T G E N-E F F L *(T G E N-T(I L 1))$ \\
\hline 36 & & FETUR'N \\
\hline 37 & 1000 & CONTINUE \\
\hline 38 & & $T(J L 1)=T H O L I I-E F F L$ 崇(THOLII-T(IL1) \\
\hline 39 & C. EFFL & IS A HEAT EXCHANGE EFFECTIUENESS BETHEE IT THE EXITIHG WEAK \\
\hline 40 & C. SOLL & UITION AHI THE INCOMIING ETFOHG SOLUTIOH \\
\hline 41 & & $X(J L 1)=X L F T(F(J L 1), T H O L I, 0.35)$ \\
\hline 42 & & $H(J L 1)=H L(X(J L 1), T(J L 1), F(J L 1))$ \\
\hline 43 & C, NOTE & THAT LIQUII IS SUECOOLEII EEFORE LEAUING EENERATOR IF EFFLつO \\
\hline 44 & C. EFF & U IS A HEAT TSANSFER EFFECTIUENESS EETHEEN THE EHTERTHE LIQUII AUII \\
\hline 45 & C. THE & EXITING VAFOF AT THE TOF OF THE GENEFATOF \\
\hline 46 & & $T(J U)=T H O L I-E F F U *(T H O L I-T(I L 1))$ \\
\hline 47 & & $F^{\prime}(J U)=F^{\prime}(J L 1)$ \\
\hline 48 & & XLTOF $=X L F T(F(J U): T(J U), 0,40)$ \\
\hline 49 & & IF (ICK,EQ.10) WEITE(LUN, \\
\hline 50 & 1 & ;T(JL1) \\
\hline 51 & & $X(J U)=X V(X L T Q F, F(J U))$ \\
\hline 52 & & $F L(J L 1)=(F L(I L 1) * X(I L 1)+F L(I L 2) * X(I L 2)-(F L(I L 1)+F L(I L 2)) * x(J U))$ \\
\hline 53 & 1 & $/(X(J L 1)-X(J \cup))$ \\
\hline 54 & & $F L(J \cup)=F L(I L 1)+F L(I L 2)-F L(J L 1)$ \\
\hline 55 & & $H(J U)=H V(X L T O F, X(J U), T(J U), F(J U))$ \\
\hline 56 & & $F=F L(I L 1) * H(I L 1)+F L(I L 2) * H(I L 2)-F L(J U)+H(J U)-F L(J L 1)+H(I L 1)+Q G E N$ \\
\hline 57 & & Go TD IJF'1 \\
\hline 58 & & ENI \\
\hline
\end{tabular}

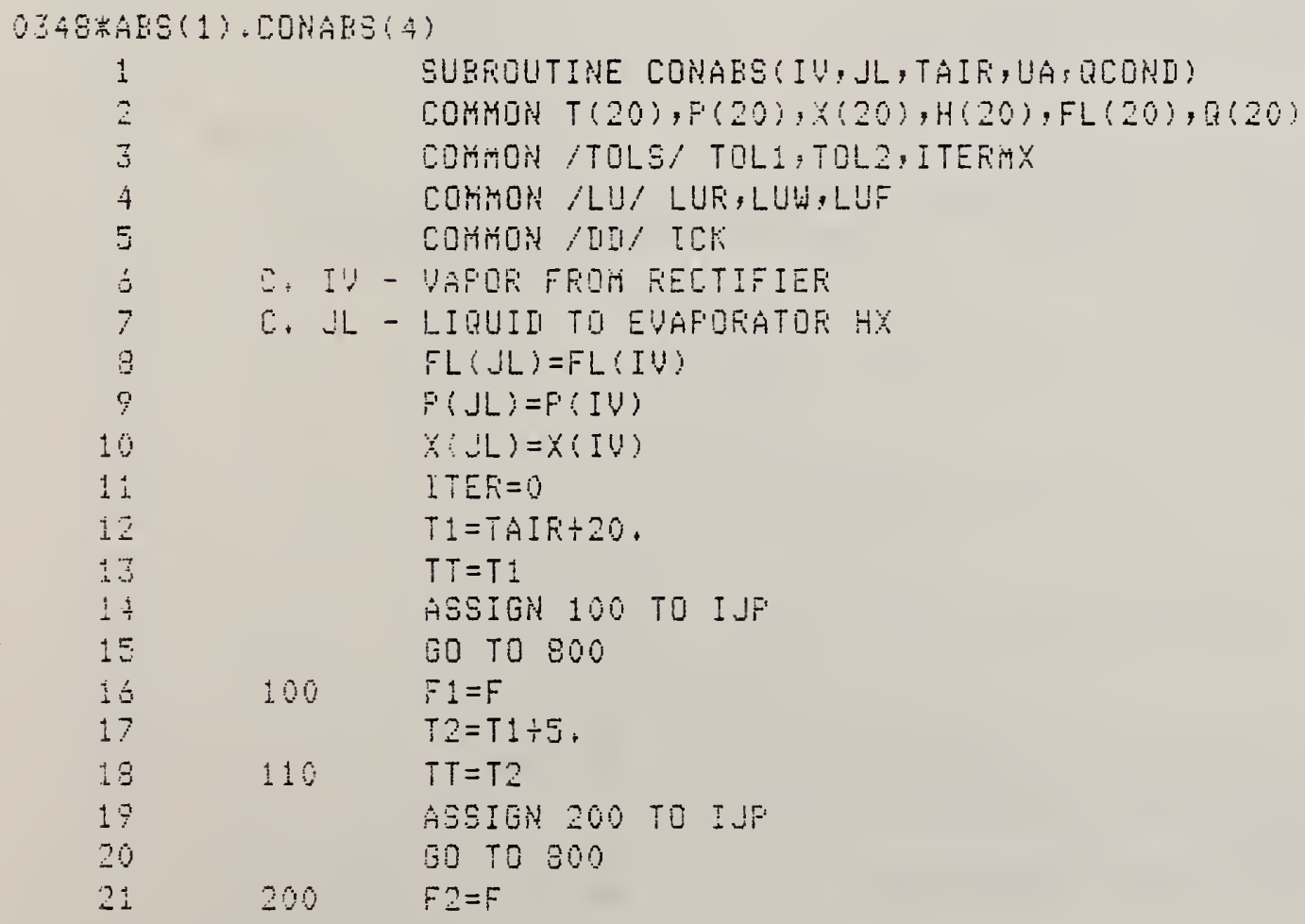




\begin{tabular}{|c|c|c|}
\hline 22 & & ITER:ITER+1 \\
\hline 23 & & IF (ITEFi,LT,ITEFIMX) GO TO 210 \\
\hline 24 & & WRITE (LUW, 230) TT,H(JL), QCONI, T(IU), X(JL) \\
\hline 25 & 230 & 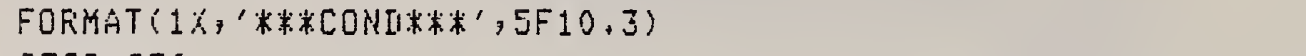 \\
\hline 26 & & STOF 230 \\
\hline 27 & 210 & CONTINUE \\
\hline 28 & & $T(J L)=T 2-F_{2} /\left(F_{2}-F_{1}\right) *\left(T_{2}-T_{1}\right)$ \\
\hline 29 & & IF (AES(T(JL)-T2),LT, TOL1) FIETUFN \\
\hline 30 & & $F 1=F 2$ \\
\hline 31 & & $T 1=T_{2}$ \\
\hline 32 & & $T 2=T(J L)$ \\
\hline 33 & & GO TO 110 \\
\hline 34 & 800 & CONTIHUE \\
\hline 35 & & $A E G=(T(I U)-T A I F) /(T T-T A I F)$ \\
\hline 36 & & IF (AFIG,GT,0.0) G0 TO 810 \\
\hline 37 & & IITLH $=0$ \\
\hline 38 & & GO TO 820 \\
\hline 39 & 810 & CONTIHUE \\
\hline 40 & & IITLH $=(T(I U)-T T) / A L O G(A F G)$ \\
\hline 41 & 820 & CONTINUE \\
\hline 42 & & QCOHII=-UAKIITL H \\
\hline 43 & & THAX $=T S A T(X(J L), F(J L))$ \\
\hline 44 & & IF (TT,GT,THAX) GO TO 850 \\
\hline 45 & C. SUEC & DOLIIEII AT OUTLET \\
\hline 46 & & $Q(J L)=0$ \\
\hline 47 & & $H(J L)=H L(X(J L), T T, F(J L))$ \\
\hline 48 & & GO TO 380 \\
\hline 49 & 850 & CONTINUE \\
\hline 50 & C. THO- & FHASE AT OUTLET \\
\hline 51 & & $X \angle I Q=X L F T(F(J L), T T, 0,8)$ \\
\hline 52 & & $X \cup A F=X \cup(X L I Q, F(J L))$ \\
\hline 53 & & $H L I Q=H L(X L I Q, T T, F(J L))$ \\
\hline 54 & & HUAF $=H \cup(X L I Q, X \cup A F, T T, F(J L j)$ \\
\hline 55 & & $Q(J L)=(X(J L)-X L I Q) /(X \vee A F-X L I Q)$ \\
\hline 56 & & $H(J L)=(1,-Q(J L)) * H L I Q+Q(J L) * H V A F$ \\
\hline 57 & 880 & COHTIHUE \\
\hline 58 & & QCON[IC $=(H(J L)-H(I U)) * F L(J L)$ \\
\hline 59 & & $F=Q \operatorname{CONII-QCONIIC}$ \\
\hline 60 & & 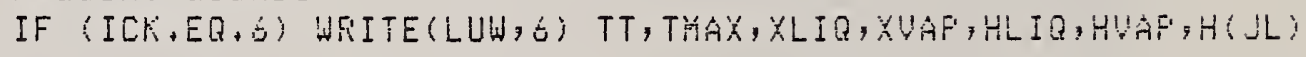 \\
\hline 61 & 1 & , Q(JL),T(IV) \\
\hline 02 & b & FOFIYAT $(1 \times, 8 F 9+3)$ \\
\hline 63 & & G0 TO IJF \\
\hline 64 & & END \\
\hline
\end{tabular}




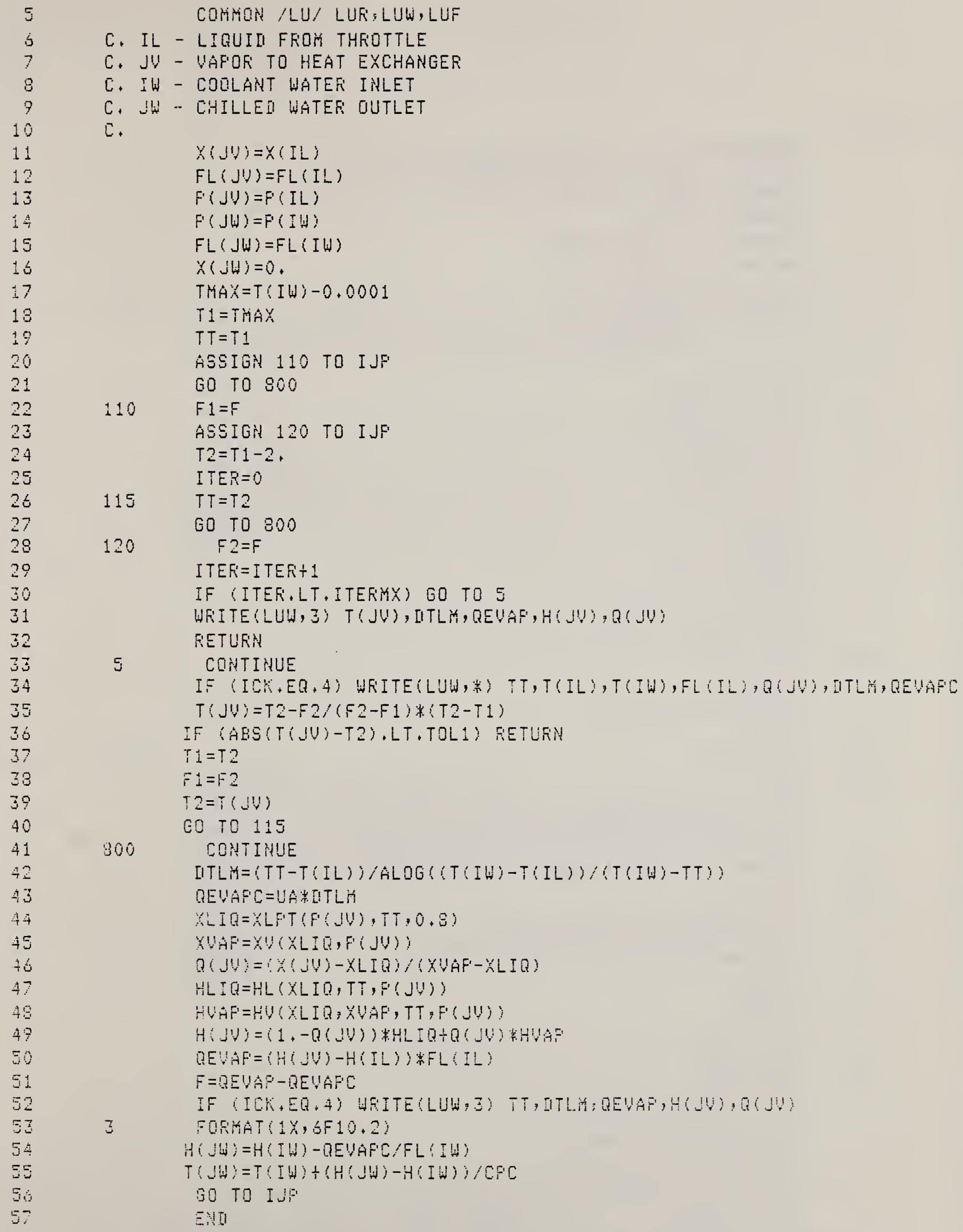


SUEROUTINE HXLU(IV,IL, JU, JL, UA)

COMMON T(20),F!20), X(20),H(20),FL(20),Q(20)

COMMON /TOLS/ TOL1, TOL2; ITERMX

COMMON /DIIICK

COMMON /LU/ LUF, LUL, LUF

C. IU - VAFOF FFOM EVAFGFATOF

C. JU - VAFOR TO AESOREEF:

C. IL - LIQUII FFOH COHIEKSOR

C. JL - LIQUII TO EVAFOEATOF

c.

$F L(J V)=F L(I L)$

$F L(I V)=F L(I L)$

$F L(J L)=F L(I L)$

$X(J U)=X(I V)$

$X(J L)=X(I L)$

$F^{\prime}(J U)=F^{\prime}(I U)$

$F^{\prime}(J L)=F^{\prime}(I L)$

ITER $=0$

$T 1=T(I L)-15$.

$T T=T 1$

ASSIGN 100 TO I JF

$100 \quad F 1=F$

GO TO 800

$T 2=T 1+5$

ASSICNN 120 TO INF

$110 \quad T T=T 2$

GO TO 800

$120 \quad F 2=F$

\section{$I T E F=I T E F+1$}

IF (ITER,LT,ITEFIYX) GO TO 150

WRITE (LUH, 130) T(JL), QX, IITLH, QX1,H(JL), H(JU)

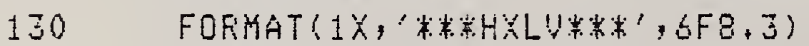

STOF

150 CONTINUE

$T(J L)=T 2-F_{2} /(F 2-F 1) *\left(T 2-T_{1}\right)$

IF (AES(T (JL)-T2),LT, TOL1) RETUFH

$F_{1}=F_{2}$

$T_{1}=T_{2}$

$T 2=T(J L)$

ED TO 110

300 CONTINUE

Q (JL) $=0$.

$H(J L)=H L(X(J L), T T, F(J L))$

$Q X=(H(I L)-H(J L))+$ t $F L(I L)$

$H(J U)=H(I Y)+Q X / F L(I U)$

$T(J V)=T Q(X(J U), F(J U), H(J U), Q(J U))$

IF $(T(J U), E E+T(I L)) \quad T(J V)=T(I L)-0,1$

$A F E=(T T-T(T U)) /(T(I L)-T(J U))$

IF (ICK,EQ+11) WFITE(LUH, 
50

51

52

53

54
II $T L H=(T T-T(I U)-T(I L)+T(J U)) / A L O G(A F G)$

QXI $=U A *[I T L H$

$F=Q X-Q \times 1$

GO TO IJF

ENII

0348*AES(1)+THFOT (0)

SUEFOUTINE THFOT(IL, JL, F'SAT)

COMKON $T(20), F(20), X(20), H(20), F L(20), Q(20)$

Fi (JL) $=$ F.SAT

ITEFT $T=0$

$X F=X(I L)$

$H(J L)=H(I L)$

$X(J L)=X(I L)$

$F L(J L)=F L(I L)$

$T(J L)=T Q\{X(J L), F(J L), H(J L), Q(J L))$

RETURN

END

10

ENI FRT

0348 *ABS(1) DIAG(1)

SUEFOUTINE IIIAG (ITEFFC, LOC)

COHMON $T(20), F(20), x(20), H(20), F L(20), Q(20)$

COMHON /LU, LUR, LUW, LUF

WRITE (LUW, 23) ITEFF'C,LOC

23

FORHAT (1X,' ITEFATIONY=', I5,' LOCATION=', IS)

[II $24 \quad I=1,16$

24 WEITE(LUW,9110) I,T(I),F(I),X(I),H(I),FL(I), QU(I)

9110 FOFHAT $(1 X, I 5,6$ F 10.3)

RETURT!

ENII

C. THESE CUFUE FITS ARE TAREN FFOH:

C. ERUILIERTUH FROFERTY [ATA EQUATIOHS FQR AQUA-AHKOUIA HTXTURES

C. F.C. JAIN AMI G. W. GAELE AGHFAE (1771) 
C. ENGLISH UNITS: $T=F, \quad X=L B / L E$ SOLN, F'=F'SIA

IF $\{F \cdot L T .200$; 60 TO 100

TSAT $=((((-240,11 * X L+346.31) * X L-27.120) * X L+166.94) * X L-535.76) * X L$

$1+(0.038839-0.18053 E-03 * F) * X L * F+305.04+(0.44631-$

$20.24284 E-03 * F ; * F$

FIETUR'?

100 CONTINUE

$T \subseteq A T=(((-692.82 * X L+1673.3) * \times L-1424.98) * \times L+787.79) * \times L-584.78) * \times L$

$1+\left(-0.34428+0.00011334 *^{\prime}\right) * F^{\prime} * X_{L}+203.90+\left(1.3362-0.0060111 * F^{\prime}\right) * F^{\prime}$ RETUEN

EHI

FUNCTION $X V(X L, F)$

IF $(X L+G T+0.9999) \quad X L=0.9999$

IF (F.LT.200,) GO TO 100

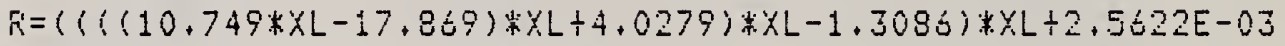

1 羊F $* X L) * X L-4,256 E-03+F^{\prime}+7,1583$

GO TO 200

100 CDNTIRUE

$\left.F_{i}=(((108.485 k \times L-229.009) \times \times L+155.247) * X L-41.0442) * X L\right)$ 称L

7

9

10

$1+11.2925-0.031256 * F+0.0213337+F * x L+2$ $X V=1,-(1,-X L) * * F_{i}$ FIETUFiN ENI 


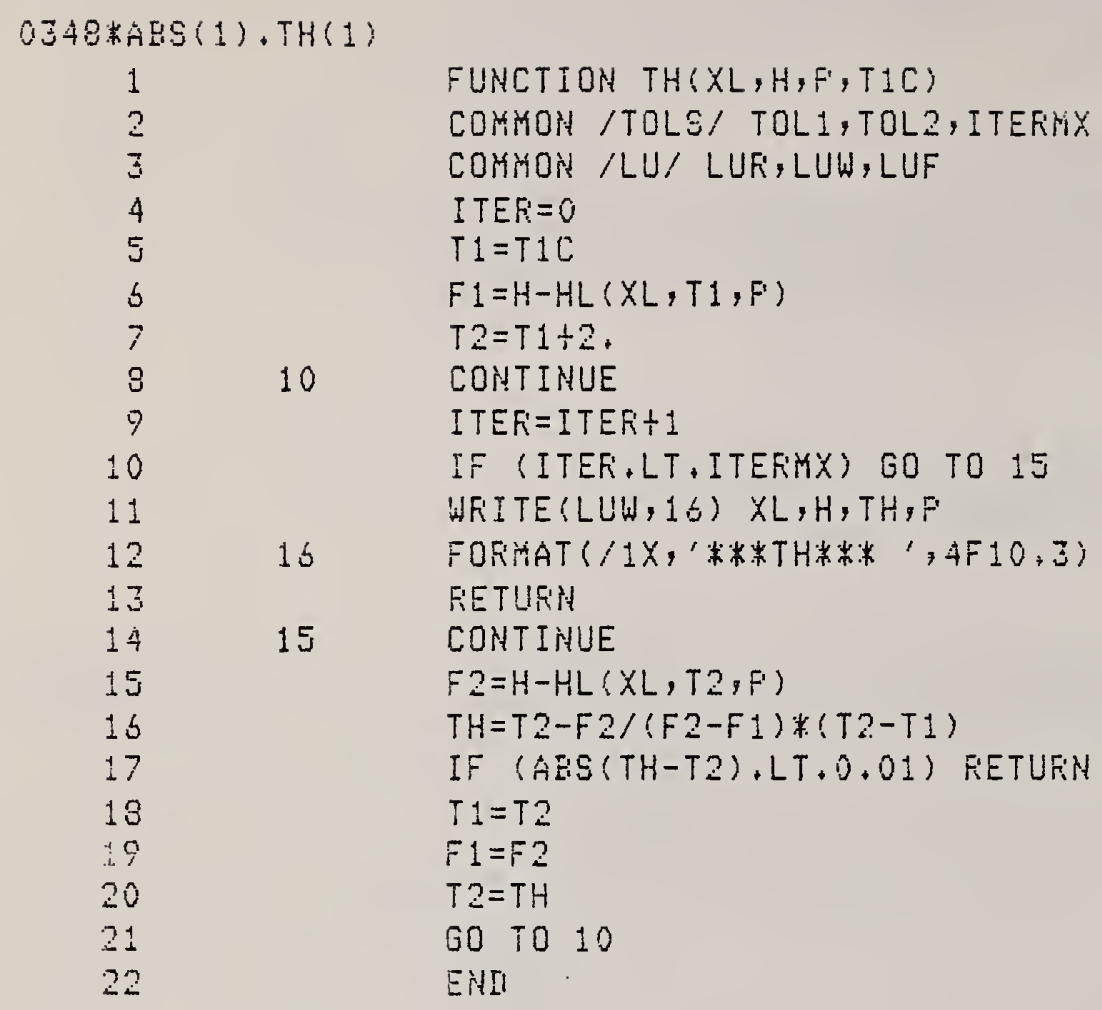

1

22

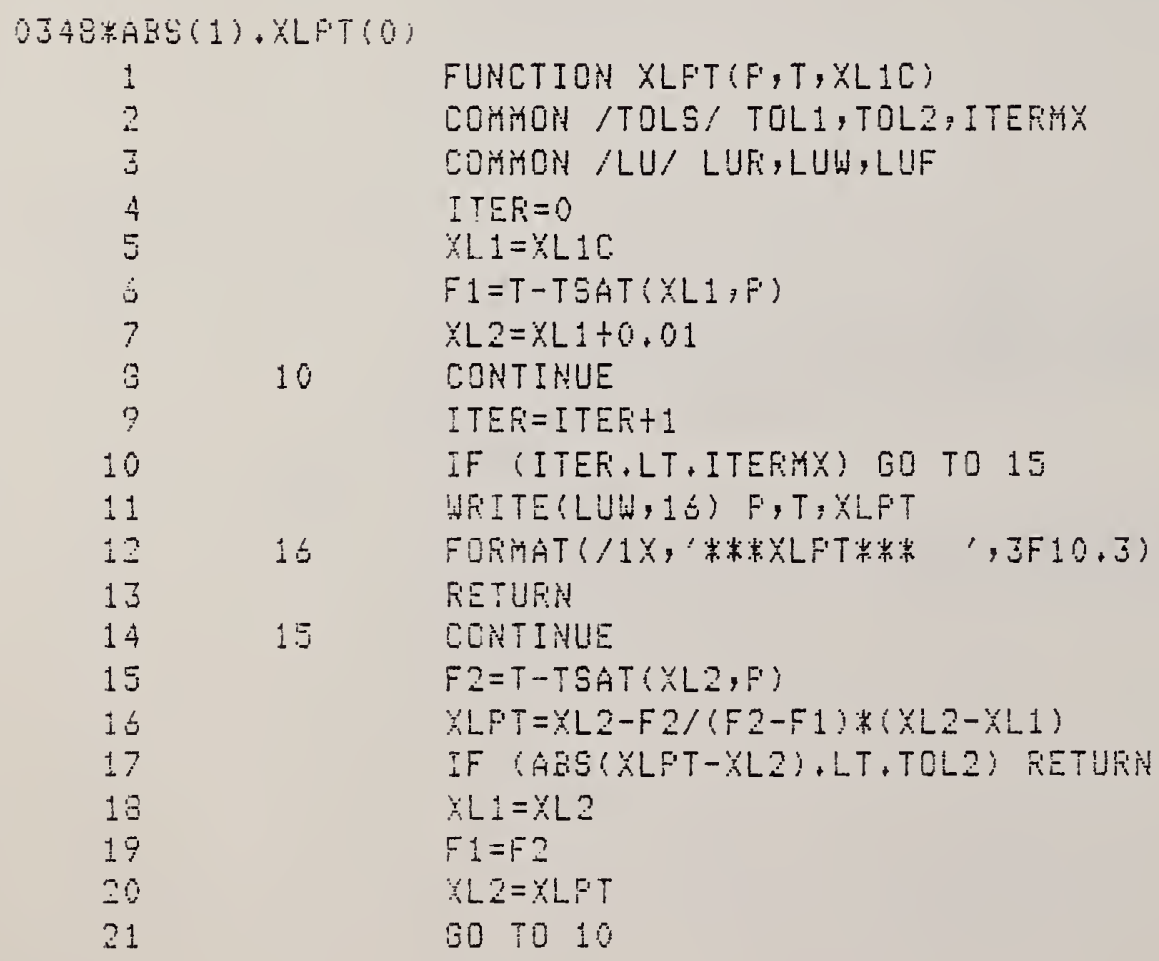

FUHCTION XLFT (F,T, XLIC)

COHAOH /TOLS/ TOL1, TOL2, ITEFH

COMHON /LU/ LUF, LUW, LUF

ITEF $=0$

$X L 1=Y L 1 C$

$F 1=T-T S A T(X L 1, F)$

$X L 2=X L 1+0.01$

10 CONTINUE

ITEF:= ITERT+1

IF (ITEF,LT, ITEFHX) GO TO 15

UFITE(LUH,16) F,T,XLFT

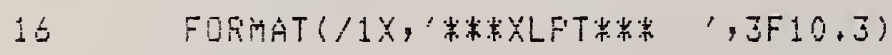

RETUEI

15 CONTINUE

F2 =T-TSAT $(X L 2, F)$

$X L F T=X L 2-F 2 /(F 2-F 1) *(X L 2-X L 1)$

IF (AES(XLFT-XL2),LT,TOL2) RETURH

$X L 1=X L 2$

$F 1=F 2$

$X L Z=X L F T$

60 TO 10 


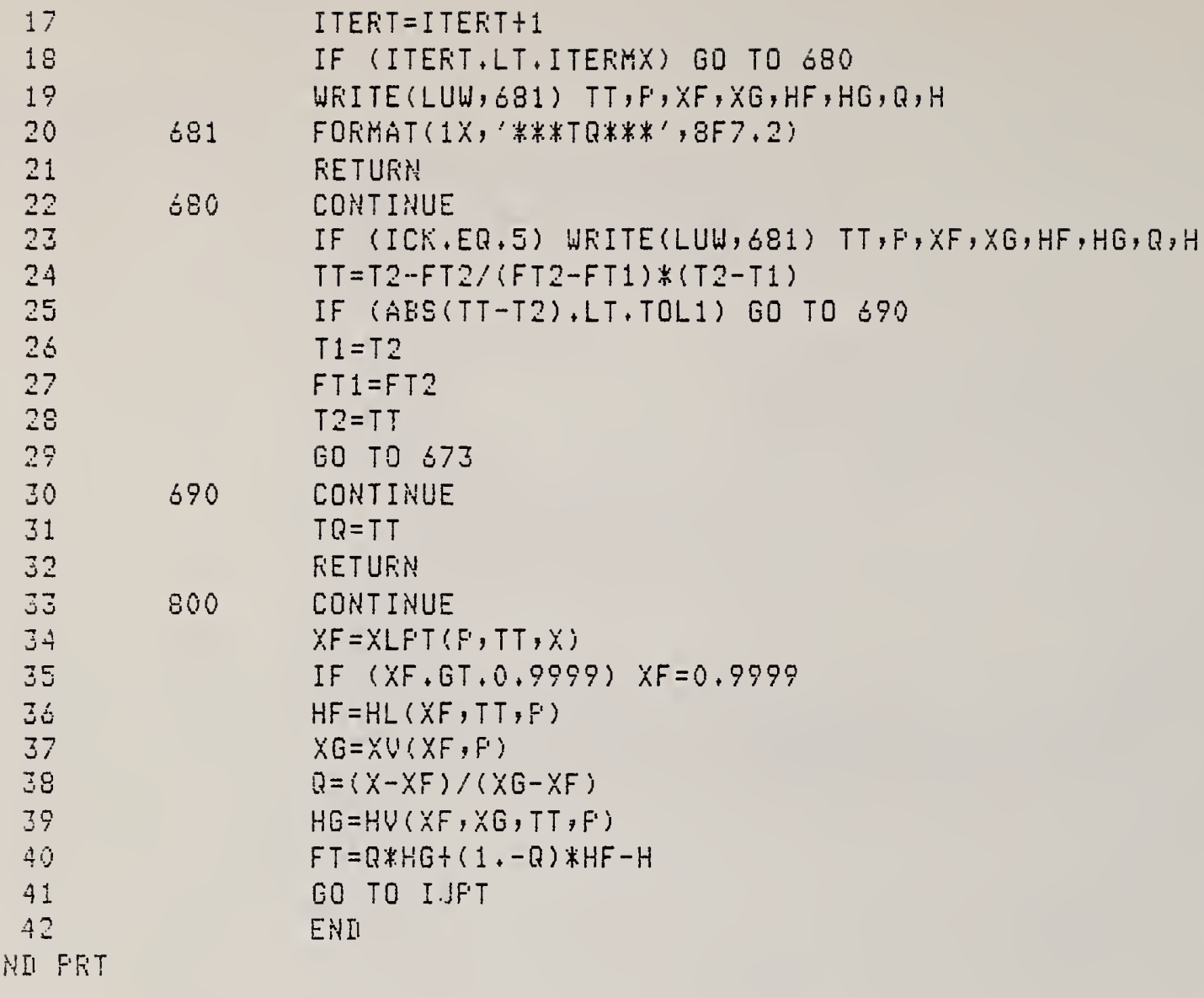


NBS.114A (REV. 2-8C)

U.S. DEPT. OF COMM.

BIBLIOGRAPHIC DATA

SHEET (See in structions)
1. PUBLICATION OR REPORT NO.

NBSIR 82-2606
2. Performing Organ. Report Nof 3. Publication Date

October 1982

4. TITLE AND SUBTITLE

A Model of the Steady-State Performance of an Absorption Heat Pump

\section{5. $\operatorname{AUTHOR}(S)$}

S. A. Klein

6. PERFORMING ORGANIZATION (If joint or other than NBS, see instructions)

7. Contract/Grant No.

NATIONAL BUREAU OF STANDARDS

DEPARTMENT OF COMMERCE

WASHINGTON, D.C. 20234

8. Type of Report \& Period Covered

9. SPONSORING ORGANIZATION NAME AND COMPLETE ADDRESS (Street, City. State, ZIP)

U.S. Department of Energy

Washington, D.C. 20585

10. SUPPLEMENTARY NOTES

Document describes a computer program; SF-185, FIPS Software Summary, is attached.

11. ABSTRACT (A 200-word or less factual summary of most significant information. If document includes a significant bibliography or literature survey. mention it here)

A mathematical model of the steady-state performance of an absorption heat pump is described. The model is compared with experimental data from a residential-sized water chiller. It is also used to determine the sensitivity of the heat pump performance to its design variables.

12. KEY WORDS (Six to twelve entries; alphabetical order: capitalize only proper names; and separate key words by semicolons) absorption heat pump; ammonia-water; ARKLA water chiller; experimental performance; mathematical model; steady-state performance

13. AVAILABILITY

X Unlimited

For Official Distribution. Do Not Release to NTIS

$\square$ Order From Superintendent of Documents, U.S. Government Printing Office, Washington, D.C. 20402.

Xrder From National Technical Information Service (NTIS), Springfield, VA. 2216I
14. NO. OF

PRINTED PAGES

56

15. Price

$\$ 9.00$ 

$-+\ldots$ 
